\title{
Does Addition of Protein to Hepatocyte or Microsomal In Vitro \\ Incubations Provide A Useful Improvement in In Vitro-In Vivo Extrapolation (IVIVE) Predictability?
}

Tsubasa Kameyama ${ }^{\mathrm{a}}$, Jasleen K. Sodhi ${ }^{\mathrm{b}}$ and Leslie Z. Benet

Department of Bioengineering and Therapeutic Sciences, Schools of Pharmacy and Medicine, University of California San Francisco, San Francisco, California

${ }^{a}$ Present address: Pharmacokinetics and Safety Assessment Department, Nippon Shinyaku Co., Ltd., Kyoto, Japan

\footnotetext{
${ }^{\mathrm{b}}$ Present address: Department of Drug Metabolism and Pharmacokinetics, Plexxikon Inc., South San Francisco, California
} 
Running title: IVIVE Predictability With In Vitro Protein Addition

Number of text pages: 26 double spaced

Number of figures and tables: 3 figures; 9 tables; 2 Supplementary tables

References: 46

Number of words in the

Abstract: 246

Introduction: 750

Discussion: 2932

Address correspondence to:

Leslie Z. Benet, Ph.D.

Department of Bioengineering \& Therapeutic Sciences

Schools of Pharmacy \& Medicine

University of California San Francisco

513 Parnassus Avenue, Room HSE-1164

San Francisco, CA 94143-0912

Vox (415) 476-3853

Fax (415) 476-8887

E-mail: leslie.benet@ucsf.edu 
ABBREVIATIONS: BDDCS, Biopharmaceutics Drug Disposition Classification System; BSA, bovine serum albumin; $C L_{H}$, hepatic clearance; $C L_{H, b}$, in vivo hepatic blood clearance; $C L_{H, p}$, in vivo hepatic plasma clearance; $C L_{\text {int }}$, intrinsic clearance; $C L_{\text {int, in vitro, with protein, in }}$ vitro intrinsic clearance derived from incubations with protein; $C L_{\text {int, in vitro, without protein, in }}$ vitro intrinsic clearance derived from incubations without protein; $C L_{\text {int, in vivo, }}$ in vivo intrinsic clearance; CYP, cytochrome P450; ECCS, Extended Clearance Classification System; EFD, Extent of Facilitated Dissociation; $E R$, extraction ratio; FABP, fatty acid binding protein; $f_{u, b}$, fraction unbound in blood; $f_{u, \text { hep }}$, fraction unbound in hepatocyte incubation; $f_{u, m i c}$, fraction unbound in microsomal incubation; $f_{u, p}$, fraction unbound in plasma; Hct, hematocrit; HSA, human serum albumin; IVIVE, in vitro-in vivo extrapolation; $K_{d}$, the dissociation equilibrium constant for the binding of a ligand to albumin; LW, liver weight; NME, new molecular entity; PBSF, physiological scaling factors; PMTE, protein-mediated transport effect; $P S_{u, i n f, x \%}$, intrinsic permeability clearance of unbound drug via influx into hepatocytes at $\mathrm{x} \%$ albumin concentration; $Q_{H, b}$, liver blood flow; $Q_{H, p}$, liver plasma flow; $R_{B P}$, blood-to-plasma partitioning ratio; UGT, UDP-glucuronosyltransferase 


\section{SIGNIFICANCE STATEMENT}

The addition of protein into microsomal or hepatocyte incubations has been widely proposed

to improve hepatic clearance predictions. To date, studies examining this phenomenon have

not included appropriate negative controls where predictability is achieved without protein

addition and have been conducted with small datasets of similar compounds that do not apply

to alternate drug classes. Here, an extensive analysis of published data for 60 drugs and 97

experimental comparisons could not validate any relevant clinically improved clearance

predictability with protein addition. 


\section{$\underline{\text { ABSTRACT }}$}

Accurate prediction of in vivo hepatic clearance is an essential part of successful and efficient drug development; however, many investigators have recognized that there are significant limitations in the predictability of clearance with a tendency for underprediction for primarily metabolized drugs. Here, we examine the impact of adding serum or albumin into hepatocyte and microsomal incubations on the predictability of in vivo hepatic clearance. The addition of protein into hepatocyte incubations has been reported to improve the predictability for high clearance (extraction ratio) drugs and highly protein bound drugs. Analyzing published data for 60 different drugs and 97 experimental comparisons (with 17 drugs being investigated from 2-7 times) we confirmed the marked underprediction of clearance. However, we could not validate any relevant improved predictability within 2 -fold by the addition of serum to hepatocyte incubations or albumin to microsomal incubations. This was the case when investigating all measurements, or when subdividing analyses by extraction ratio, degree of protein binding, BDDCS class, examining ECCS class 1B drugs only or drug charge. Manipulating characteristics of small data sets of like compounds and adding scaling factors can appear to yield good predictability, but the carryover of these methods to alternate drug classes and different laboratories is not evident. Improvement in predictability of poorly soluble compounds is greater than that for soluble compounds but not to a meaningful extent. Overall, we cannot 
confirm that protein addition improves IVIVE predictability to any clinically meaningful degree when considering all drugs and different subsets.

KEY WORDS: IVIVE; hepatic clearance; fraction unbound; protein addition; protein-facilitated uptake 


\section{Introduction}

Drug discovery and development is an extremely expensive, time-consuming process with a poor success rate. It is well recognized that an accurate prediction of an NME's (new molecular entity's) pharmacokinetic properties prior to any in vivo studies could improve the efficiency of drug development. Clearance is one of the most important pharmacokinetic parameters, as clearance determines drug exposure (which drives drug efficacy and potential toxicity), and directly contributes to projection of safe and efficacious NME dosing regimens.

Metabolic stability studies are routinely conducted to predict in vivo drug clearance for metabolized drugs in the early drug discovery stage, where various approaches to predict in vivo clearance from in vitro systems, such as utilization of microsomes and hepatocytes, have been established as recently reviewed (Sodhi and Benet, 2021). Attempting to predict in vivo hepatic clearance using the in vitro-in vivo extrapolation (IVIVE) method involves measuring an intrinsic clearance $\left(\mathrm{CL}_{\text {int }}\right)$, defined as the intrinsic ability of liver to remove drug in the absence of protein binding or flow limitations in microsomes or hepatocytes, and applying biological scaling factors and a liver model to scale the in vitro measures to predict the in vivo hepatic clearance. However, a tendency for significant underprediction from the IVIVE method for primarily metabolized drugs and for drugs where clearance is rate limited by hepatic uptake has been documented (Bowman and Benet, 2016; Wood et al., 2017; Kim et al., 2019). 
Recently, we examined the theoretical basis of IVIVE predictions from first principles, suggesting a number of future pathways that should be investigated towards improved IVIVE success (Benet and Sodhi, 2020).

Here, we focus on the effect of adding serum or protein, such as albumin, to hepatocyte and microsomal incubations. It has been reported that hepatocyte incubations with $100 \%$ serum more accurately predict in vivo hepatic clearance in rats (Blanchard et al., 2004) and humans (Blanchard et al., 2005 and 2006). Additionally, it has been reported that albumin could improve predictions of in vivo hepatic clearance from microsomal incubations. Furthermore, based on human hepatocyte studies, considerable underprediction of in vivo hepatic clearance $\left(C L_{H}\right)$, especially of highly protein bound OATP1B1 substrate drugs, has been widely reported (Soars et al., 2007; Zou et al., 2013). These $\mathrm{CL}_{H}$ predictions are improved (but still result in underpredictions) by inclusion of plasma or plasma proteins (e.g., albumin) in human hepatocyte transport studies. This has been attributed to the observed higher intrinsic uptake clearance (passive and active) in the presence of plasma proteins (Kim et al., 2019; Bowman et al., 2020). These data have led to the hypothesis of a protein-mediated transport effect (PMTE) (Miyauchi et al., 2018). We recently reviewed the evolution of the fraction unbound terms included when implementing IVIVE, the concept of protein-facilitated uptake, and the mechanisms that have been proposed to account for facilitated uptake (Bowman and 
Benet, 2018). Although protein-facilitated uptake has been mainly reported as the mechanism for the serum albumin effect in hepatocyte incubations (Kim et al., 2019; Bowman and Benet, 2018; Bowman et al., 2019; Bteich et al., 2019), the mechanism is not clearly understood. Protein-mediated increased predictability is also observed in microsomal preparations, and we maintain that this may be due to the lack of detailed testing of multiple negative control substrates for which the albumin-effect is not expected. We propose the possibility that for any poorly soluble compound, the addition of protein in in vitro incubations may enhance assay conditions by preventing non-specific binding and potentially boosting drug concentrations available for metabolism.

Here, to examine the effect of adding protein to metabolic stability incubations, we compiled measured $\mathrm{CL}_{\text {int }}$ values from hepatocyte and microsomal incubations with and without protein addition and compared the accuracy of in vivo $\mathrm{CL}_{H}$ predictions from these data using the IVIVE method. Since plasma, serum or human serum albumin (HSA) is typically added to metabolic stability incubations rather than blood, and due to the potential inaccuracies in determination of fraction unbound in the blood $\left(f_{u, b}\right)$ for transporter substrates as we have recently noted (Benet and Sodhi, 2020), we evaluated IVIVE accuracy in terms of plasma clearance in addition to the typically reported blood clearance-based IVIVE assessment. We also examined the protein effect on IVIVE success with respect to drug properties such as the 
extraction ratio (ER), the extent of protein binding, the Biopharmaceutics Drug Disposition Classification System (BDDCS) (Wu and Benet, 2005) (to examine the impact of IVIVE success on low versus high solubility drugs), charge class, and for the drug subset where clearance is rate limited by hepatic OATP uptake.

\section{Methods}

Data Collection. In vitro $\mathrm{CL}_{\text {int }}$ values derived from incubations with protein $\left(\mathrm{CL}_{\text {int, in vitro, with }}\right.$ protein) were collected from 7 studies for human hepatocytes for 52 drugs, with 73 individual drug measurements (values presented in Supplementary material, Table S-1) (Shibata et al., 2002; Bachmann et al., 2003; Blanchard et al., 2006; Chao et al., 2009; Mao et al., 2012; Nishimuta et al., 2019; Kim et al., 2019) and 12 studies for human microsomes for 15 drugs with 24 individual measurements (values presented in Supplementary material, Table S-2) (Ludden et al., 1997; Carlile et al., 1999; Tang et al., 2002; Baba et al., 2002; Rowland et al.,2007, 2008a and 2008b; Wattanachai et al., 2011 and 2015; Walsky et al., 2012; Gill et al., 2012; Palacharila et al., 2017). A total of 60 different drugs were evaluated here. In these investigations, the authors incubated human hepatocytes with $100 \%$ human serum or $1-5 \%$ HSA, and human microsomes with $2-4 \%$ HSA or bovine serum albumin (BSA). From the numbers above, often the same drug was included in multiple investigations with the addition of serum. To avoid the detrimental impact of variability between laboratories, we scaled up 
each measurement separately rather than averaging in vitro $\mathrm{CL}_{\text {int }}$ values from multiple investigations. In vitro $\mathrm{CL}_{\text {int }}$ values derived from human hepatocyte and microsomal incubations without serum $\left(\mathrm{CL}_{\text {int, in vitro, without protein }}\right)$ were collected from the above mentioned publications in priority, however, the Nishimuta et al., (2019) and Shibata et al. (2002) studies did not evaluate incubations without protein ( 26 drugs, 28 measurements). To maintain comparisons with and out without protein addition $\mathrm{CL}_{\text {int, in vitro, without protein }}$ values from the Wood et al. (2017) data base were incorporated (see Supplementary Information Tables S-1 and S-2). A number of drugs were excluded from this analysis because either corresponding $\mathrm{CL}_{\text {int, in vitro, without protein }}$ values were unavailable or there was not a reliable estimate of in vivo clearance listed in either the Wood et al. (2017) database or the Lombardo et al. (2018) database of IV clearance of 1352 drugs. For human hepatocytes, these drugs were: atomoxetine, buspirone, cisapride, disopyramide, felodipine, fentanyl, fluconazole, fluoxetine, ketoconazole, lansoprazole, mebendazole, moferatone, mycophenolic acid, nicardipine, nimodipine, oxybutynin, paclitaxel, paroxetine, rivastigmine, telmisartan, tolcapone, ziprasidone and zoniporide. For human microsomes, these drugs were: amodiaquine, bupropion, chlorzoxazone, dextromethorphan, ezetimibe, mephenytoin, terfenadine, trifluoperazine and 5-hydroxytryptophol. Additionally, tolbutamide from the Carlile et al. (1999) study was excluded as concentration-dependent binding was observed and unbound $\mathrm{CL}_{\text {int }}$ could thus not be calculated from reported data. 
In Vitro-In Vivo Extrapolation Approach. $\mathrm{CL}_{\text {int,in vitro, with protein }}$ and $\mathrm{CL}_{\text {int,in vitro, without protein }}$ were scaled

to whole liver in vivo total and in vivo unbound values using Eq. 1.

$$
\text { Predicted } C L_{\text {int, in vivo, with or without protein }}=\frac{C L_{\text {in vitro, with or without protein } \cdot P B S F \cdot L W}}{f_{u, \text { hep }} \text { or } f_{u, \text { mic }}}
$$

To ensure that consistent scaling factors were employed for all investigations, we used the physiological scaling factors (PBSFs) for hepatocellularity and a microsomal recovery factor of $120 \times 10^{6}$ hepatocytes/g liver and $40 \mathrm{mg}$ microsomal protein/g liver. Liver weight (LW) was assumed to be $21.4 \mathrm{~g} / \mathrm{kg}$ body weight. Fraction unbound in hepatocyte $\left(\mathrm{f}_{\mathrm{u} \text {,hep }}\right)$ and microsomal incubations $\left(f_{u, m i c}\right)$ were taken from the original publications, however, if $f_{u \text {,hep }}$ with and without $100 \%$ human serum was not reported, we used fraction unbound in plasma $\left(f_{u, p}\right)$ and $f_{u, \text { hep }}$ from the published data bases mentioned above (Wood et al., 2017; Lombardo et al., 2018). For procainamide, bufuralol and drugs studied in the Kim et al. (2019) investigation, $f_{u, \text { hep }}$ was estimated from an empiric relationship as indicated in Supplementary Table S1. Predicted blood in vivo hepatic clearance ( $\left.\mathrm{CL}_{\mathrm{H}, \mathrm{b}}\right)$ was scaled using the well-stirred model (Eq. 2).

Predicted $C L_{H, b}=\frac{Q_{H, b} \cdot f_{u, b} \cdot \text { Predicted } C L_{i n t, \text { in vivo,with or without protein }}}{Q_{H, b}+f_{u, b} \cdot \text { Predicted } C L_{\text {int, in vivo,with or without protein }}}$

Liver blood flow $\left(Q_{H, b}\right)$ was assumed to be $20.7 \mathrm{~mL} / \mathrm{min} / \mathrm{kg}$, and fraction unbound in blood $\left(f_{u, b}\right)$ was referenced from the published data set of Wood et al. (2017) and for the OATP rate limited drugs from Kim et al. (2019). For the drugs that are not listed in the Wood et al. (2017) compilation, $f_{u, b}$ values were derived from the quotient of $f_{u, p}$ and the reported 
blood-to-plasma partitioning ratio $\left(R_{B P}\right)$. For the drugs that did not have reported $R_{B P}$ values, we assumed the value to be equal to 1 for a basic or neutral compound and 0.55 (1-hematocrit) for an acidic compound.

When calculating predicted $\mathrm{CL}_{H, b}$, the value of $f_{u, b}$ is required to scale up predicted in vivo $\mathrm{CL}_{\text {int }}\left(\mathrm{CL}_{\text {int, in vivo }}\right)$ values. However, our laboratory has recently recognized that determinations of $f_{u, b}$ may be inaccurate for transporter substrates (Benet and Sodhi, 2020). This is because calculations of $f_{u, b}$ from measurements of $f_{u, p}$ and the $R_{B P}$ ratio relies on the free drug theory, under the theoretical assumption that free unbound concentrations in the plasma are equal to free drug concentrations within the red blood cell - a scenario that is not valid for substrates of transporters expressed in the erythrocyte membrane. Therefore, we also evaluated IVIVE-error associated with $\mathrm{CL}_{H, p}$ to avoid using $\mathrm{f}_{\mathrm{u}, \mathrm{b}}$. In calculations of predicted $\mathrm{CL}_{\mathrm{H}, \mathrm{p}}$, utilization of the liver plasma flow $\left(Q_{H, p}\right)$ is required. $Q_{H, p}$ was calculated with Eq. 3, where the liver blood flow was $20.7 \mathrm{~mL} / \mathrm{min} / \mathrm{kg}$, and hematocrit (Hct) was 0.45 .

$Q_{H, p}=Q_{H, b} \cdot(1-H c t)=Q_{H, b} \cdot 0.55=11.4 \mathrm{~mL} / \mathrm{min} / \mathrm{kg}$

Predicted $\mathrm{CL}_{\mathrm{H}, \mathrm{p}}$ was determined from predicted $\mathrm{CL}_{\text {int,in vivo,with or without protein, unbound }}$ using the well-stirred model (Eq. 4).

Predicted $C L_{H, p}=\frac{Q_{H, p} \cdot f_{u, p} \cdot \text { Predicted } C L_{\text {int }, \text { in vivo,with or without protein }}}{Q_{H, p}+f_{u, p} \cdot \text { Predicted } C L_{\text {int }, \text { in vivo, with or without protein }}}$

To investigate the effect of serum or HSA addition for hepatic clearance prediction, 
we collected observed $\mathrm{CL}_{\mathrm{H}, \mathrm{b}}$ (Wood et al., 2017) and $\mathrm{CL}_{\mathrm{H}, \mathrm{p}}$ (Lombardo et al., 2018) values and compared IVIVE-error (predicted $\mathrm{CL}_{\mathrm{H}, \mathrm{b}} /$ observed $\mathrm{CL}_{H, b}$ or predicted $\mathrm{CL}_{\mathrm{H}, \mathrm{p}} /$ observed $\mathrm{CL}_{H, \mathrm{p}}$ ) with and without serum. For the drugs that are not listed in the Wood et al. (2017) compilation, $\mathrm{CL}_{H, \mathrm{~b}}$ values were derived from the quotient of $\mathrm{CL}_{H, p}$ and $\mathrm{R}_{\mathrm{BP}}$. Plasma clearance values reported in Lombardo et al. (2018) were total clearance values, however since the drugs evaluated in this dataset are primarily metabolized BDDCS class 1 and 2 drugs (with minor contribution of renal and biliary elimination), total plasma clearance was assumed to reflect only hepatic clearance. We used ER values of $\leq 0.3$ and $\geq 0.7$ as the cutoffs for low and high ER, respectively, to investigate any potential clearance-dependent trends in IVIVE success. The drugs with ER between 0.3 and 0.7 were defined as moderate ER. For the 11 drugs where clearance is believed to be rate limited by OATP hepatic uptake, the $\mathrm{CL}_{\text {int }}$ values are, in fact, the intrinsic hepatic uptake clearances. As we have reviewed previously (Benet et al., 2018), when intrinsic hepatic basolateral efflux is negligible or much smaller than the sum of intrinsic hepatic metabolic and biliary clearance, the well-stirred model relationship substituting intrinsic hepatic uptake clearance for intrinsic hepatic elimination clearance is valid. Additionally, we investigated the trends related to BDDCS (Wu et al., 2005; Benet et al., 2011; Hosey et al., 2016), charge class, clearance category and protein binding in terms of prediction accuracy of in vivo hepatic clearance. 


\section{Results}

Initially, we made a comparison of clearance-dependent IVIVE-error with and without

protein addition for both blood and plasma clearance (Fig. 1), visually confirming the clearance-dependent underprediction error recognized by the field for hepatocyte and microsomal incubations (Hallifax et al., 2010; Bowman and Benet, 2016 and 2019). Tables 1 and 2 report the predictability of hepatocyte and microsome data, respectively, within 2 -fold of total clearance for all drugs, then divided based on ER (low, moderate and high). For the hepatocyte results of $\mathrm{CL}_{\mathrm{H}, \mathrm{b}}$ without serum, predictability accuracy within 2-fold for all, low, moderate, and high ER drugs was 32.4\%, 31.3\%, 34.5\% and 30.0\%, respectively, suggesting that there was no discrimination based on extraction ratio. In the results with serum addition, predictability within 2-fold for all, low, moderate, and high ER drugs was $41.1 \%, 46.9 \%, 32.3 \%$, and $50.0 \%$, respectively, again demonstrating a similar IVIVE prediction success for all clearance categories in the presence of protein and a slight overall increase as compared to the predictions without serum. A similar trend was observed for hepatocyte predictions of $\mathrm{CL}_{\mathrm{H}, \mathrm{p}}$, with all, low, moderate and high ER drugs without serum providing IVIVE accuracies within 2-fold of $17.9 \%, 22.7 \%, 26.7 \%$ and $10.0 \%$ and in the presence of protein were $27.5 \%, 50.0 \%$, $31.3 \%$ and $9.7 \%$. A similar outcome is observed in Table 2 for addition of protein into microsomal incubations. In the absence of albumin, IVIVE accuracies within 2-fold for $\mathrm{CL}_{\mathrm{H}, \mathrm{b}}$ for 
all, low, moderate and high ER drugs were $20.8 \%, 25.0 \%, 28.6 \%$ and $11.1 \%$ and in the presence of albumin were $37.5 \%, 25.0 \%, 42.9 \%$ and $44.4 \%$. Additionally, in the absence of albumin, IVIVE microsomal based accuracies within 2-fold for $\mathrm{CL}_{\mathrm{H}, \mathrm{p}}$ for all, low, moderate and high ER drugs were $20.8 \%, 25.0 \%, 60.0 \%$ and $0.0 \%$ and in the presence of albumin were $33.3 \%, 37.5 \%$, $100.0 \%$ and $0.0 \%$ (Table 2 ).

To examine the relationship between IVIVE predictability and protein binding, we examined the potential for $f_{u, b}\left(\right.$ or $\left.f_{u, p}\right)$-dependent IVIVE error with and without serum (Fig. 2). For the hepatocyte results of $\mathrm{CL}_{\mathrm{H}, \mathrm{b}}$ without serum, $14.7 \%$ accurate prediction within 2-fold was obtained for highly-bound drugs with $\mathrm{f}_{\mathrm{u}, \mathrm{b}}$ less than 0.1 , while $48.6 \%$ was obtained for drugs with $f_{u, b} 0.1$ or more (Table 3 ). The addition of serum yielded $40.0 \%$ accurate prediction within 2 -fold for drugs with $f_{u, b}$ less than 0.1 , while $42.1 \%$ for drugs with $f_{u, b} 0.1$ or more. A similar trend is observed for hepatocyte IVIVE predictions of $\mathrm{CL}_{H, p}$, with the percent within 2-fold for highly bound drugs ( $f_{u, p}$ less than 0.1 ) increasing from $8.8 \%$ to $37.1 \%$ with the addition of serum and for low-binding drugs ( $f_{u, p}$ greater than 0.1 ) decreasing from $27.3 \%$ to $17.6 \%$ within 2 -fold in the presence of serum. These results indicate that $f_{u}$-dependent IVIVE error is apparent for the hepatocytes incubations without serum (Fig. 2A, C; red dots), with larger underprediction errors for those drugs with $f_{u, b}$ or $f_{u, p}$ values less than 0.1 , and the addition of serum into the hepatocytes incubation (Fig. 2A, C; green dots) improves IVIVE for highly-bound drugs with $f_{u}$ 
values less than 0.1, while minimal or decreasing changes are observed for low binding drugs.

A different outcome is observed (Table 4) for addition of albumin into microsomal incubations, with respect to IVIVE accuracy for poorly versus highly bound drugs. For highly bound drugs, IVIVE accuracies within 2-fold for $\mathrm{CL}_{H, \mathrm{~b}}$ were $28.6 \%$ and did not change in the presence of albumin $(28.6 \%)$, but for low binders predictability within 2 -fold improved from $10.0 \%$ to $50.0 \%$. For $\mathrm{CL}_{\mathrm{H}, \mathrm{p}}$, success within 2 -fold for highly bound drugs without albumin was $35.7 \%$ and this value decreased to $28.6 \%$ in the presence of albumin. For poorly bound drugs, a marked increase in IVIVE success was observed with the addition of albumin, with values increasing from $0.0 \%$ to $30.0 \%$ for $\mathrm{CL}_{\mathrm{H}, \mathrm{p}}$. These results indicate that the addition of albumin into microsomal incubations only improves IVIVE for poorly bound drugs with $f_{u}$ values 0.1 or more, the opposite result to the general belief that addition of protein increases the prediction preferentially for highly bound drugs in hepatocyte incubations.

We further investigated the association of BDDCS class with IVIVE-error with and without serum addition, comparing highly soluble Class 1 and 3 drugs versus poorly soluble Class 2 and 4 drugs to test whether protein addition may have had a larger effect on poorly soluble drugs. For hepatocyte incubations without serum when predicting $\mathrm{CL}_{\mathrm{H}, \mathrm{b}}, 39.5 \%$ accurate predictions within 2-fold were obtained for BDDCS class 1 and 3 drugs, while $21.4 \%$ 
were obtained for BDDCS class 2 and 3 drugs (Table 5). The addition of serum had minimal effects for BDDCS class 1 and 3 drugs (39.5\% to 43.2\%), while for BDDCS class 2 and 4 drugs predictability increased from $21.4 \%$ to $37.9 \%$. For hepatocyte $\mathrm{CL}_{\mathrm{H}, \mathrm{p}}$ values, the addition of serum had little effect on correct predictability of Class 1 and 3 drugs (without serum 20.9\%; with serum 20.5\%) but as for the blood clearance values, predictability as seen in Table 5 was lower for the Class 2 and 4 drugs (12.5\%) and increased markedly with the addition of serum (40.0\%). For microsome data (Table 6), all 24 drugs are BDDCS Class 1 and 2. There are only 7 Class 1 evaluations to be considered and therefore it is difficult to draw conclusions with confidence, but for the 17 Class 2 drug evaluations, $\mathrm{CL}_{\mathrm{H}, \mathrm{B}}$ correct percentages increased from $17.6 \%$ to $29.4 \%$ with the addition of serum, while $\mathrm{CL}_{\mathrm{H}, \mathrm{P}}$ correct percentages increased from $23.5 \%$ to $41.2 \%$ (Table 6 ).

The association between IVIVE predictability and charge class was also conducted with and without serum addition (Tables 7 and 8). For the hepatocyte results of $\mathrm{CL}_{\mathrm{H}, \mathrm{b}}$ without serum, predictability within 2 -fold for acid, basic, and neutral drugs was $11.1,45.2 \%$, and $35.0 \%$, respectively, and in the presence of serum were $31.6 \%, 46.9 \%$, and $40.0 \%$, respectively (Table 7). Zwitterions are also listed in the tables, but there were so few compounds that they are not addressed here. Results for prediction of $\mathrm{CL}_{\mathrm{H}, \mathrm{p}}$ were similar, with predictability within 2-fold for acid, base and neutral drugs without protein addition of $5.9 \%, 22.6 \%$ and $23.5 \%$ and 
in the presence of protein, these values were $33.3 \%, 28.1 \%$, and $17.6 \%$. These results indicate that the addition of serum into hepatocyte incubations seems to improve IVIVE for acidic drugs, but never more than 34\%. Basic and neutral drugs give higher predictability without serum addition and there was little improvement of IVIVE with protein addition. For the subset of acidic OATP rate limited substrates, as reported by Kim et al. (2019), addition of protein increased estimated clearance predictions, but only 3 of the 10 drugs tested with HSA addition then yielded values within 2-fold predictability. In the microsomal results (Table 8 ) of $\mathrm{CL}_{\mathrm{H}, \mathrm{b}}$ and $\mathrm{CL}_{H, P}$ predictability was higher for acidic drugs than for neutral drugs, exhibiting no effect on neutral drug predictability. Only one weakly basic drug, midazolam, was investigated in microsomes and its predictability became within 2-fold with protein addition. These results indicate that the addition of albumin in microsomal incubations improves IVIVE for acidic drugs, although IVIVE success is still quite low, never exceeding $50 \%$ in the presence of protein.

Finally, we investigated the effect that protein addition had on the magnitude of increase of $\mathrm{CL}_{\text {int,in vivo }}$ values in hepatocyte and microsomal incubations (Fig. 3 and Table 9) to evaluate the potential for protein-facilitated uptake that could occur in hepatocytes (due to the presence of membranes and transporters) but not in the microsomal incubations. In hepatocytes, serum addition exhibited decreased $\mathrm{CL}_{\text {int, in vivo }}$ in $42.5 \%$ of all drugs examined. The percentage of compounds that showed this decrease was greater in the BDDCS class 1 (51.2\%) 
than the class $2(33.3 \%)$ compounds, reflecting the inaccuracy of poorly soluble compounds without serum addition and the greater increase in predictability seen with poorly soluble compound when protein was added. With the addition of serum into hepatocyte incubations, $31.7 \%$ of BDDCS class 1 drugs increased $\mathrm{CL}_{\text {int, in vivo }}$ more than 2 -fold, while $55.6 \%$ of $\mathrm{BDDCS}$ class 2 drugs increased $\mathrm{CL}_{\text {int,in vivo }}$ more than 2 -fold. As seen in Fig. 3B, protein addition had a much greater increase in predictability for microsome measurements than for hepatocyte measurements. With the addition of albumin into microsomal incubations, $42.9 \%$ of BDDCS

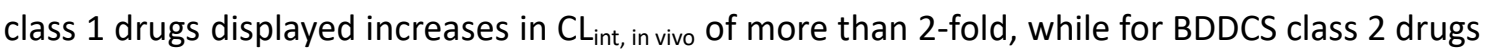
this value was $76.5 \%$. These results highlight that the addition of serum/albumin into the hepatocyte/microsomal incubations tended to markedly increase (greater than 2-fold) unbound intrinsic clearance of a larger percentage of the poorly soluble BDDCS class 2 , in comparison to the highly soluble BDDCS class 1 drugs.

\section{Discussion}

Accurate prediction of in vivo hepatic clearance is an integral part of successful and efficient drug development. Although IVIVE methodologies are commonly used to predict in vivo hepatic clearance, it has been demonstrated for decades by many investigators that there are significant limitations in predictability of clearance. A tendency for significant 
underprediction for primarily metabolized drugs has been reported (Bowman and Benet, 2016;

Wood et al., 2017; Benet and Sodhi, 2020) and for drugs where clearance is rate limited by hepatic uptake (Zou et al., 2013; Kim et al., 2019). Moreover, it has been reported that the predictability of in vivo hepatic clearance is poor for the drugs that are highly bound to protein in blood (Francis et al., 2021). As we (Bowman and Benet, 2018) and Poulin et al. (2016) have reviewed, when conducting in vitro studies, many groups have reported that adding plasma or serum to hepatocyte incubations and adding albumin to microsome incubations can cause decreases in free $K_{m}$ values and improved IVIVE results (Ludden et al., 1997; Carlile et al., 1999; Baba et al., 2002; Shibata et al., 2002; Tang et al. 2002; Blanchard et al., 2004, 2005 and 2006; Rowland et al., 2007, 2008a and 2008b; Chao et al., 2009; Wattanachai et al., 2011, 2012 and 2015; Mao et al., 2012; Walsky et al., 2012; Gill et al., 2012; Palacharila et al., 2017; Fujino et al., 2018; Nishimuta et al., 2019; Kim et al., 2019; Bowman et al., 2019; Bteich et al., 2019) (values presented in Supplementary material, Tables S-1 and S-2). Here we review these 24 studies together to test the validity of this conclusion. For each of these investigations, we emphasize the importance of measuring incubational binding for all $\mathrm{CL}_{\text {int }}$ determinations, in order to accurately predict clearance based on the in vitro conditions in each laboratory as well as to account for non-specific binding or high protein binding characteristics inherent for certain compounds. We also acknowledge the potential challenges of accurately measuring in vitro 
intrinsic clearance values for highly bound drugs in the presence of protein (particularly those that exhibit low in vitro turnover) and for poorly soluble or highly lipophilic drugs in the absence of protein due to the low amounts of available drug in the incubation.

First, as seen for all drugs in Table 1 the addition of serum only yields minimal increases in 2-fold predictability for hepatocyte blood clearance measurements (32.4\% 2-fold predictability without serum addition and $41.1 \%$ with serum addition) and hepatocyte plasma clearance measurements (17.9 \% without serum and $27.5 \%$ with serum). Slightly higher percentage increases are observed for microsomal measurements, but still not good predictability as seen in Table $2(20.8 \%$ without albumin versus $37.5 \%$ with albumin addition for blood measurements, and $20.8 \%$ without versus $33.3 \%$ with albumin addition for plasma measurements). From the 73 individual blood clearance predictions with human hepatocytes for 52 different drugs and the 24 individual blood clearance predictions with human microsomes for 15 different drugs, 7 drugs were evaluated in both hepatocytes (14 predictions; $28.6 \%$ predicted within 2 -fold without serum and this increased to $42.9 \%$ with serum addition) and microsomes (12 predictions; $25.0 \%$ predicted within 2 -fold without albumin addition and this increased to $33.3 \%$ with albumin addition) as seen in Tables S-1 and S-2. The percentage of predictions within 2-fold for this subset were very similar to that reported in Tables 1 and 2 for the entire data set. Comparison of low, moderate and high extraction ratio for all drugs in 
Tables 1 and 2 yielded no obvious consistent differences based on ER for the four different measurements (hepatocyte and microsome, blood and plasma values). We believe that it is relevant that no dependence on ER was found, as low ER compounds would provide clearance measurements that are the same for all the hepatic models of organ elimination.

In Fig. 2 and Tables 3 and 4 we tested the hypothesis that predictability of in vivo hepatic clearance is poor for drugs that are highly bound to protein in blood as proposed by Soars et al. (2007), by using the cutoff of $f_{u, p}<0.1$. For hepatocyte incubations, IVIVE success of $\mathrm{CL}_{H, b}$ within 2-fold for highly bound drugs increases from $14.7 \%$ without serum to $40.0 \%$ with serum, while poorly bound drugs IVIVE success decreases from $48.6 \%$ without serum to $42.1 \%$ with serum (Table 3). Similar results were observed for plasma measurements. In contrast, for microsomal incubations, IVIVE success for blood measurements within 2-fold for highly bound drugs does not change with albumin (28.6\%), while poorly bound drugs IVIVE success increases from $10 \%$ without albumin to $50 \%$ with albumin (Table 4). Again, similar results are seen with plasma measurements. However, the contrasting trends for microsomes versus hepatocytes were surprising as it was expected that serum addition for highly bound compounds would improve IVIVE predictions in both matrices.

Most recently, Francis et al. (2021) also reported increased predictability in the presence of protein for highly protein bound drugs. There are significant differences between 
the Francis et al. (2021) analysis and the material presented here that readers should consider.

Francis et al. (2021) evaluated both human and rat hepatocyte data, but no microsome measurements for 22 drugs, of which 9 were from the published study of Kim et al. (2019) for acidic extended clearance classification (ECCS, Varma et al., 2015) 1B substrates where clearance is rate limited by hepatic OATP uptake. The present analysis of 52 drugs for 73 experimental human hepatocyte investigations, includes all 22 drugs analyzed by Francis et al. (2021) from 36 experimental human hepatocyte measurements. Thus, it is possible that better predictability occurs for highly bound ECCS Class 1B drugs (OATP substrates), but our results suggest this is not carried over to all highly bound drugs.

IVIVE success with and without protein addition was investigated with respect to BDDCS class (Wu and Benet, 2005). Both BDDCS class 1 and 2 drugs are primarily metabolized due to their high permeability characteristics; however, BDDCS class 1 drugs have high solubility, while BDDCS class 2 drugs have poor solubility. It has been proposed that the high solubility characteristics of BDDCS class 1 drugs allow for rapid membrane passage of drug at high soluble concentrations, deeming any potential involvement of xenobiotic transporters clinically insignificant. However, due to the low solubility characteristics of BDDCS class 2 drugs, the potential for transporter involvement cannot be ruled out as passive diffusion may not occur at high enough concentrations to overwhelm any potential transporter-mediated 
involvement in drug disposition. Thus, the primarily metabolized BDDCS class 2 drugs may or may not also be transporter substrates. BDDCS Class 3 and 4 drugs are expected to be substrates for transporter mediated processes but differ in terms of solubility.

In the present study, the addition of serum into the hepatocyte incubations did not improve in vivo $\mathrm{CL}_{H, b}$ prediction for highly soluble BDDCS class 1 and 3 (39.5\% without serum; 43.2\% with serum) (Table 5). Poorly soluble BDDCS class 2 and 4 drugs exhibited lower predictability without serum $(21.4 \%)$, which increased to a comparable $37.9 \%$ with serum addition (Table 5). We had speculated that the presence of protein in in vitro incubations may be enhancing assay conditions for low-solubility compounds, by preventing non-specific binding and potentially boosting drug concentrations available for metabolism. We also analyzed the effect of albumin addition in the microsomal incubations on IVIVE predictability, where the potential for protein-facilitated uptake is not a possibility due to the lack of cell membranes and transporters in such incubations. No data for BDDCS class 3 and 4 drugs are available. In Table 6 for the microsome incubations, improvement of IVIVE success is noted with serum addition, with a marked increase from $28.6 \%$ to $57.1 \%$ for BDDCS class 1 blood measurements but no change from $14.3 \%$ for plasma measurements. However, only 7 BDDCS class 1 drug measurements were available in microsomes (versus 17 for BDDCS class 2) so the class 1 change in blood measurements may be suspect. Class 2 compounds displayed increases 
in IVIVE predictability with albumin addition (from $17.6 \%$ to $29.4 \%$ for blood values and $23.5 \%$

to $41.2 \%$ for plasma values), though overall predictability within 2 -fold is still quite low with protein addition.

In Fig. 3, we plot the individual unbound intrinsic clearance values from hepatocyte incubations (Fig. 3A) and microsome incubations (Fig. 3B) with respect to BDDCS class, visually highlighting the tendency of the addition of albumin into the incubations to increase unbound intrinsic clearance of both BDDCS class 1 and class 2 drugs in both hepatocyte and microsomal incubations. Although the mechanism of the protein effect in hepatocytes has frequently been cited as protein-facilitated uptake, in microsomes it has been suggested that the protein effect is due to albumin trapping the unsaturated long-chain fatty acids that can inhibit the activity of CYPs and UGTs (Rowland et al.,2007, 2008a and 2008b; Wattanachai et al., 2011, 2012 and 2015; Palacharila et al., 2017). The unsaturated long-fatty acids are present in the hepatocytes, but most of them are trapped to fatty acid-binding proteins (FABPs), and thus it is thought that the concentration of the unsaturated long-fatty acids would not be high enough to inhibit CYP and UGT isoforms activities (Fujino et al., 2018). It would be expected that trapping of the inhibitory fatty acids via protein addition in microsomal incubations would increase in vitro unbound $\mathrm{CL}_{\text {int }}$ values of BDDCS class 1 and 2 drugs equally, as both classes are primarily metabolized. The microsomal data in Table 6 confirms that the protein effect is apparent for 
both BDDCS class 1 and 2, however, a greater percentage of Class 2 drugs displayed increases in unbound intrinsic clearance greater than 2 -fold (70.6\% versus $42.9 \%)$, suggesting that additional factors (such as improvement of solubility) may also be contributing.

Our laboratory has recently pointed out (Benet and Sodhi, 2020) that although values of $f_{u, b}$ are required to predict in vivo blood clearance using the IVIVE method, there is potential for error in calculation of $f_{u, b}$ from experimental determination of $f_{u, p}$ and measurements of $R_{B P}$ ratios. Experimental $f_{u, b}$ values are usually calculated by Eq. 5 .

$f_{u, b}=\frac{f_{u, p}}{R_{B P}}$

To derive Eq. 5, one must assume that free drug concentrations are equal in the blood cells and the plasma. However, transporters have been identified in the blood cell membrane and this assumption may not hold for transporter substrates expressed in erythrocytes. Therefore, it is possible that this inaccuracy of $f_{u, b}$ may impact poor IVIVE prediction (Benet and Sodhi, 2020). And thus, we also conducted the analysis of $\mathrm{CL}_{\mathrm{H}, \mathrm{p}}$ IVIVE to avoid using $\mathrm{f}_{\mathrm{u}, \mathrm{b}}$. However, the $\mathrm{CL}_{H, \mathrm{p}}$ analyses did not result in improved IVIVE predictions as compared to the $\mathrm{CL}_{H, b}$ analysis. We generally have greater faith in the blood level measurements. When attempting to use the plasma values, we had to assume that plasma flow was (1-hematocrit) multiplied by hepatic blood flow with a resulting plasma flow of $11.4 \mathrm{ml} / \mathrm{min} / \mathrm{kg}$ as given in Eq. 3 . It is generally accepted that the $\mathrm{CL}_{\mathrm{H}, \mathrm{p}}$ value cannot exceed $\mathrm{Q}_{\mathrm{H}, \mathrm{p}}$. However, we found that 18 of the 49 drugs 
for which plasma measurements were analyzed, $C_{H, p}$ values were greater than the $Q_{H, p}$ value of $11.4 \mathrm{~mL} / \mathrm{min} / \mathrm{kg}$ (Supplementary Tables S-1 and S-2). In contrast, 3 of the 49 drugs reported $Q_{H, b}$ values greater than $20.7 \mathrm{~mL} / \mathrm{min} / \mathrm{kg}$. The difference in frequency of the plasma clearances exceeding plasma hepatic flow is 6 -fold greater than when it occurred for the blood clearances exceeding blood flow.

We also investigated the effect of charge class on the predictability within 2-fold of observed in vivo hepatic clearance as depicted in Table 7 for hepatocyte measurements and Table 8 for microsome measurements. In the presence of protein, there appears to be a modest increase in predictability for neutrals in hepatocytes but not for microsomes and a doubling of the percentage accuracy for acids in both hepatocytes and microsomes, but accuracy is never greater than $50 \%$. For bases, serum addition caused little improvement in accuracy in hepatocytes. Only one base were studied in microsomes. It is interesting to note that the IVIVE success in the presence of protein between hepatocytes and microsomes was similar (ranging from 31.6-50\%) for acids, a class of drugs for which the rate-limiting hepatic uptake is well-documented throughout the literature (Kim et al., 2019). One may have anticipated that if rate-limiting steps based on the Extended Clearance Model (as we reviewed, Benet et al., 2018) or ECCS were relevant, that there would be differences between the IVIVE success of hepatocytes (where the possibility of rate-limited uptake exists) versus microsomes 
(where there is no such possibility), yet IVIVE success was approximately $31.6-50 \%$ for both matrices in the presence of protein.

Returning to ECCS class 1B drugs, it is instructive to note that Bi et al. (2021) investigated 8 ECCS class 1B drugs in human hepatocytes (with the addition of plasma compared to buffer) that were also reported by Kim et al. (2019) for studies in human hepatocytes (with the addition of 5\% HSA compared to buffer). Both Bi et al. (2021) and Kim et al. (2019) report that adequate predictions can only be achieved by using a scaling factor, i.e., 2.44 (Kim et al., 2019) and 3.8-5.3 (Bi et al., 2021). This approximately 2-fold difference in scaling factor reflects that significant differences in predictability are found in different, highly respected laboratories for the same drugs, and emphasizes the need for future studies comparing the effects of different amounts of added protein as well as different experimental systems. It is important to note that the unbound $\mathrm{CL}_{\text {int }}$ of Kim et al. (2019) for uptake of OTAP substrates was determined using the oil-spin method, while $\mathrm{CL}_{\text {int }}$ values of the other data sets cited in our analysis were mainly determined by the conventional hepatocyte stability assay (measuring the compound disappearance in hepatocyte incubation). The two methods could lead to significant differences in underestimation of hepatic clearance for hepatic uptake transporter substrates, although neither method gives IVIVE predictions within 2-fold with protein addition. Even more recently the Sugiyama laboratory, guided by their understanding 
of the facilitated-dissociation model obtained from the 10 highly protein-bound anionic drugs analyzed by Kim et al. (2019), proposed a simplified method to predict the hepatic uptake clearance in vivo (in the presence of the physiological $5 \%$ albumin concentration) for these 10 drugs (Miyuachi et al., 2021). In this simplified method, Miyauchi et al. (2021) introduced the concept of the Extent of Facilitated Dissociation (EFD) where the increase of intrinsic (unbound) hepatic influx clearance with albumin added $\left(\mathrm{PS}_{\mathrm{u}, \mathrm{inf}, 5 \%}\right)$ for these 10 anionic substrates may be predicted from the measured intrinsic uptake clearance in the absence of albumin $\left(\mathrm{PS}_{\mathrm{u}, \mathrm{inf}, 0 \%}\right)$ using Eq. 6

$$
P S_{u, i n f, 5 \%}=P S_{u, i n f, 0 \%} \cdot\left(1+\frac{E F D}{K_{d}}\right)
$$

They reported that an EFD value of $11 \mu \mathrm{M}$ and a dissociation equilibrium constant for the binding of a ligand to albumin $\left(\mathrm{K}_{\mathrm{d}}\right)$ value of $46 \mu \mathrm{M}$ could be used for all the 10 substrates rather than measuring the 5\% albumin PS value. Miyauchi et al. (2021) report that the prediction of hepatic clearance obtained by the simplified method was comparable with those obtained by the previously proposed method utilizing the measurement of the protein binding and hepatic uptake at varying concentrations of albumin. Whether this facilitated dissociation model for a particular subset of drugs (highly protein bound OATP substrates) (Kim et al., 2019; Miyauchi et al., 2021) and other studies proposing protein-facilitated uptake via the presence of an albumin-specific receptor on the hepatocyte surface, rate-limiting dissociation of ligand from a 
protein-ligand complex, rate-limiting diffusion of ligand through an unstirred water layer, interactions with the hepatocyte cell surface (as reviewed by Poulin et al., 2016 and Bowman and Benet, 2018), as well as our proposed transporter-induced protein binding shift (Bowman et al., 2019) we emphasize that all of these studies do not include the appropriate controls, i.e. drugs giving good IVIVE predictions without the addition of protein. For example, another very recent article by Bteich et al. (2021) shows excellent improvement in hepatic clearance predictivity for fluoxetine and perampanel using a newly proposed extrapolation approach, but like other proposed methodologies does not validate the approach by testing a drug showing good predictability without protein addition. We are not suggesting that this last study and others do not show increased predictability with the addition of protein, just that the conclusions regarding the proposed hypotheses being tested by these investigators (regardless of the methodology utilized) can only be validated by also including drugs that exhibit good predictability without protein addition. In all the analyses reviewed thus far, there appears to be minimal support for the hypothesis that protein addition provides a clinically meaningful increase in IVIVE predictability when all published drugs investigated in hepatocyte and microsomal incubations are considered.

When a presentation such as this proposes that a well-accepted methodology has little use, the scientific community, of course, questions the data upon which this conclusion is 
made. Here, we only review the published data. However, in our very recently accepted manuscript (Benet and Sodhi, 2022) we report that the original concept of the "albumin mediated hepatic uptake" is based on invalid assumptions and that, in fact, there is no theoretical basis upon which IVIVE should be expected to work, as it doesn't. However, the scattered literature data upon which our conclusions here are based probably requires that prospective, well-controlled experimental studies in a single laboratory will be needed to rigorously determine whether adding protein in any form to in vitro determinations of clearance improves the IVIVE and whether any improvement can be tied to chemical structure, physical properties (e.g., solubility, charge) and clearance mechanism, before the scientific community abandons the concept. We would welcome such a study.

\section{CONCLUSIONS}

The present manuscript demonstrates for the available experimental data that addition of protein to in vitro incubations of hepatocytes and microsomes does not improve IVIVE predictability in a useful manner. Analyzing published data for 60 different drugs and 97 experimental comparisons (with 17 drugs being investigated from 2-7 times) we confirmed the marked underprediction of clearance previously reported. The addition of protein into hepatocyte incubations has been reported to improve the predictability for high clearance (extraction ratio) drugs and highly protein bound drugs. However, we could not validate any 
relevant improved predictability within 2 -fold by the addition of serum to hepatocyte incubations or albumin to microsomal incubations. This was the case when investigating all measurements, or when subdividing analyses by extraction ratio, degree of protein binding, BDDCS class, examining ECCS class 1B drugs only or drug charge.

For the 73 human hepatocyte studies, adding protein decreased predictability in $42.5 \%$ of the evaluations. Manipulating characteristics of small data sets of similar compounds and adding scaling factors can appear to yield good predictability, but the carryover of these methods to alternate drug classes and different laboratories is not evident. Improvement in predictability of poorly soluble compounds is greater than that for soluble compounds but not to a meaningful extent. Overall, we cannot confirm that protein addition improves IVIVE predictability to any meaningful degree when considering all drugs and different subsets. 


\section{Funding Information}

This work was supported in part by a Mary Anne Koda-Kimble Seed award for

innovation. Mr. Kameyama's tenure in the UCSF Benet laboratory was supported by Nippon

Shinyaku Co., Ltd., Japan. Dr. Sodhi was supported in part by an American Foundation for

Pharmaceutical Education Pre-Doctoral Fellowship, NIGMS Grant R25 GM56847 and a Louis

Zeh Fellowship. Dr. Benet is a member of the UCSF Liver Center supported by NIH Grant P30

DK026743.

\section{Authorship Contributions}

Participated in research design: Kameyama, Sodhi and Benet

Performed data analysis: Kameyama 
Wrote or contributed to writing of the manuscript: Kameyama, Sodhi and Benet

\section{Financial Statement}

The authors declare that they have no actual or perceived conflicts of interest with the contents of this work.

\section{References}

Baba T, Touchi A, Ito K, Yamaguchi Y, Yamazoe Y, Ohno Y, and Sugiyama Y (2002) Effects of serum albumin and liver cytosol on CYP2C9- and CYP3A4-mediated drug metabolism.

Drug Metab Pharmacokinet 17:522-531.

Bachmann K, Byers J, and Ghosh R (2003) Prediction of in vivo hepatic clearance from in vitro data using cryopreserved human hepatocytes. Xenobiotica 33:475-483.

Benet LZ and Sodhi JK (2020) Investigating the theoretical basis for in vitro-in vivo extrapolation (IVIVE) in predicting drug metabolic clearance and proposing future experimental pathways. AAPS J 22:120.

Benet LZ and Sodhi JK (2022) Can in vitro in vivo extrapolation (IVIVE) be successful? 
Recognizing the incorrect clearance assumptions. Clin Pharmacol Ther in press, 2021 Nov

3. doi: $10.1002 / c p t .2482$.

Benet LZ, Bowman CM, Liu S, and Sodhi JK (2018) The extended clearance concept following oral and intravenous dosing: Theory and critical analysis. Pharm Res 35:242.

Benet LZ, Broccatelli F, Oprea TI (2011) BDDCS applied to over 900 drugs. AAPS J 13:519547.

Bi Y-a, Ryu S, Tess DA, Rodrigues AD, and Varma MVS (2021) Effect of human plasma of organic anion-transporting polypeptide 1B substrates: Studies using transfected cell and primary human hepatocytes. Drug Metab Dispos 49:72-83.

Blanchard N, Alexandre E, Abadie C, Lavé T, Heyd B, Mantion G, Jaeck D, Richert L, and Coassolo P (2005) Comparison of clearance predictions using primary cultures and suspensions of human hepatocytes. Xenobiotica 35:1-15.

Blanchard N, Hewitt NJ, Silber P, Jones H, Coassolo P, and Lave T (2006) Prediction of hepatic clearance using cryopreserved human hepatocytes: a comparison of serum and serum-free incubations. J Pharm Pharmacol 58:633-641.

Blanchard N, Richert L, Notter B, Delobel F, David P, Coassolo P, and Lave T (2004) Impact 
of serum on clearance predictions obtained from suspensions and primary cultures of rat hepatocytes. Eur J Pharm Sci 23:189-199.

Bowman CM and Benet LZ (2016) Hepatic clearance predictions from in vitro-in vivo extrapolation and the biopharmaceutics drug disposition classification system. Drug Metab Dispos 44:1731-1735.

Bowman CM and Benet LZ (2018) An examination of protein binding and protein-facilitated uptake relating to in vitro-in vivo extrapolation. Eur J Pharm Sci 123:502-514.

Bowman CM, Okochi $\mathrm{H}$, and Benet LZ (2019) The presence of a transporter-induced protein binding shift: A new explanation for protein-facilitated uptake and improvement for in vitro-in vivo extrapolation. Drug Metab Dispos 47:358-363.

Bowman CM, Chen E, Chen L, Chen Y, Liang X, Wright M, Chen Y, and Mao J (2020) Changes in organic anion transporting polypeptide uptake in HEK293 overexpressing cells in the presence and absence of human plasma. Drug Metab Dispos 48:18-24.

Bteich M, Poulin P, and Haddad S (2019) The potential protein-mediated hepatic uptake: Discussion on the molecular interactions between albumin and the hepatocyte cell surface and their implications for the in vitro-to-in vivo extrapolations of hepatic 
clearance of drugs. Expert Opin Drug Metab Toxicol 15:633-658.

Bteich M, Poulin P, and Haddad S (2021) Comparative assessment of extrapolation methods based on the conventional free drug hypothesis and plasma-mediated hepatic uptake theory for the hepatic clearance predictions of two drugs extensively bound to both albumin and alpha-1-acid glycoprotein. J Pharm Sci 110:1385-1391.

Carlile DJ, Hakooz N, Bayliss MK, and Houston JB (1999) Microsomal prediction of in vivo clearance of CYP2C9 substrates in humans. Br J Clin Pharmacol 47:625-635.

Chao P, Barminko J, Novik E, Han Y, Maguire T, and Cheng K-C (2009) Prediction of human hepatic clearance using an in vitro plated hepatocyte clearance model. Drug Metab Lett

3:296-307.

Francis LJ, Houston JB, and Hallifax D (2021) Impact of plasma protein binding in drug clearance prediction: a database analysis of published studies and implications for in vitro in vivo extrapolation. Drug Metab Dispos 49:188-201.

Fujino R, Hashizume K, Aoyama S, Maeda K, Ito K, Toshimoto K, Lee W, Ninomiya S, and Sugiyama $Y$ (2018) Strategies to improve the prediction accuracy of hepatic intrinsic clearance of three antidiabetic drugs : Application of the extended clearance concept and 
consideration of the effect of albumin on CYP2C metabolism and OATP1B-mediated hepatic uptake. Eur J Pharm Sci 125:181-192.

Gill L, Houston JB, and Galetin A (2012) Characterization of in vitro glucuronidation clearance of a range of drugs in human kidney microsomes: Comparison with liver and intestinal glucuronidation and impact of albumin. Drug Metab Dispos 40:825-835.

Hallifax D, Foster JA, and Houston JB (2010) Prediction of human metabolic clearance from in vitro systems: Retrospective analysis and prospective view. Pharm Res 27:21502161.

Hosey CM, Chan R, and Benet LZ (2016) BDDCS predictions, self-correcting aspects of BDDCS assignments, BDDCS assignment corrections, and classification for more than 175 additional drugs. AAPS J 18:251-260.

Kim S, Lee K, Miyauchi S, and Sugiyama Y (2019) Extrapolation of in vivo hepatic clearance from in vitro uptake clearance by suspended human hepatocytes for anionic drugs with high binding to human albumin: Improvement of in vitro-to-in vivo extrapolation by considering the "albumin-mediated" hepatic uptake mechanism on the basis of the "facilitated-dissociation model". Drug Metab Dispos 47:94-103 
Lombardo F, Berellini G, and Obach RS (2018) Trend analysis of a database of intravenous pharmacokinetic parameters in humans for 1352 drug compounds. Drug Metab Dispos 46:1466-1477.

Ludden LK, Ludden TM, Collins JM, Pentikis HS, and Strong JM (1997) Effect of albumin on the estimation, in vitro, of phenytoin $V_{\max }$ and $\mathrm{K}_{\mathrm{m}}$ values: Implications for clinical correlation ${ }^{1}$. J Pharmacol Exp Ther 282:391-396.

Mao J, Mohutsky MA, Harrelson JP, Wrighton SA, and Hall SD (2012) Predictions of cytochrome P450-Mediated drug-drug interactions using cryopreserved human hepatocytes: Comparison of plasma and protein-free media incubation conditions. Drug Metab Dispos 40:706-716.

Miyauchi S, Masuda M, Kim S, Tanaka Y, Lee K, Iwakado S, Nemoto, Sasaki S, Shimono K, Tanaka Y, and Sugiyama Y (2018) The phenomenon of albumin-mediated hepatic uptake of organic anion transport polypeptide substrates: prediction of the in vivo uptake clearance from the in vitro uptake by isolated hepatocytes using a facilitated-dissociation model. Drug Metab Dispos 46:259-267.

Miyauchi S, Kim S, Lee W, and Sugiyama Y (2021) Consideration of albumin-mediated hepatic uptake for highly protein-bound anionic drugs: Bridging the gap of hepatic uptake clearance between in vitro and in vivo. Pharmacol Ther Jun 24:107938. doi: 
10.1016/j.pharmthera.2021.107938. Online ahead of print.

Nishimuta H, Watanabe T, and Bando K (2019) Quantitative prediction of human hepatic clearance for P450 and non-P450 substrates from in vivo monkey pharmacokinetics study and in vitro metabolic stability tests using hepatocytes. AAPS J 21:20.

Palacharla RC, Uthukam V, Manoharan A, Ponnamaneni RK, Padala NP, Boggavarapu RK, Bhyrapuneni G, Ajjala DR, and Nirogi R (2017) Inhibition of cytochrome P450 enzymes by saturated and unsaturated fatty acids in human liver microsomes, characterization of enzyme kinetics in the presence of bovine serum albumin $(0.1$ and $1.0 \% \mathrm{w} / \mathrm{v})$ and in vitro - in vivo extrapolation of hepatic clearance. Eur J Pharm Sci 101:80-89.

Poulin P, Burczynski FJ, and Haddad S (2016) The role of extracellular binding proteins in the cellular uptake of drugs: Impact on quantitative in vitro-to-in vivo extrapolations of toxicity and efficacy in physiologically based pharmacokinetic-pharmacodynamic research. J Pharm Sci 105:497-508.

Rowland A, Gaganis P, Elliot DJ, Mackenzie PI, Knights KM, and Miners JO (2007) Binding of inhibitory fatty acids is responsible for the enhancement of UDP-glucuronosyltransferase 2B7 activity by albumin: Implications for in vitro-in vivo extrapolation. J Pharmacol Exp Ther 321:137-147. 
Rowland A, Elliot DJ, Knights KM, Mackenzie PI, and Miners JO (2008a) The "albumin effect" and in vitro-in vivo extrapolation: Sequestration of long-chain unsaturated fatty acids enhances phenytoin hydroxylation by human liver microsomal and recombinant cytochrome P450 2C9. Drug Metab Dispos 36:870-877.

Rowland A, Knights KM, Mackenzie PI, and Miners JO (2008b) The "albumin effect" and drug glucuronidation: Bovine serum albumin and fatty acid-free human serum albumin enhance the glucuronidation of UDP-glucuronosyltransferase (UGT) 1A9 substrates but not UGT1A1 and UGT1A6 activities. Drug Metab Dispos 36:1056-1062.

Shibata Y, Takahashi H, Chiba M, and Ishii Y (2002) Prediction of hepatic clearance and availability by cryopreserved human hepatocytes: An application of serum incubation method. Drug Metab Dispos 30:892-896.

Soars MG, McGinnity DF, Grime K, and Riley RJ (2007) The pivotal role of hepatocytes in drug discovery. Chem Biol Interact 168:2-15.

Sodhi JK and Benet LZ (2021) Successful and unsuccessful prediction of human hepatic clearance for lead optimization. J Med Chem 64:3546-3559.

Tang C, Lin YUH, Rodrigues AD, and Lin JH (2002) Effect of albumin on phenytoin and 
tolbutamide metabolism in human liver microsomes: An impact more than protein binding. Drug Metab Dispos 30:648-654.

Varma MV, Steyn SJ, and El-Kattan AF (2015) Predicting clearance mechanism in drug discovery: Extended Clearance Classification System (ECCS). Pharm Res 32:3785-3802.

Walsky RL, Bauman JN, Bourcier K, Giddens G, Lapham K, Negahban A, Ryder TM, Obach RS, Hyland R, and Goosen TC (2012) Optimized assays for human UDP-glucuronosyltransferase (UGT) activities: Altered alamethicin concentration and utility to screen for UGT Inhibitors. Drug Metab Dispos 40:1051-1065.

Wattanachai N, Polasek TM, Heath TM, Uchaipichat V, Tassaneeyakul W, Tassaneeyakul W, and Miners JO (2011) In vitro-in vivo extrapolation of CYP2C8-catalyzed paclitaxel $6 \alpha$-hydroxylation: Effects of albumin on in vitro kinetic parameters and assessment of interindividual variability in predicted clearance. Eur J Clin Pharmacol 67:815-824.

Wattanachai N, Tassaneeyakul W, Rowland A, Elliot DJ, Bowalgaha K, Knights KM, and Miners JO (2012) Effect of albumin on human liver microsomal and recombinant CYP1A2 activities: Impact on in vitro-in vivo extrapolation of drug clearance. Drug Metab Dispos 
40:982-989.

Wattanachai N, Tassaneeyakul W, and Tassaneeyakul W (2015) The effects of bovine serum albumin on kinetic characterization of human liver microsomal CYP2C19 and CYP2E1 activities. Thai J Pharmacol 37:27-40.

Wood FL, Houston JB, and Hallifax D (2017) Clearance prediction methodology needs fundamental improvement: Trends common to rat and human hepatocytes/microsomes and implications for experimental methodology. Drug Metab Dispos 45:1178-1188.

Wu CY and Benet LZ (2005) Predicting drug disposition via application of BCS: Transport/absorption/ elimination interplay and development of a biopharmaceutics drug disposition classification system. Pharm Res 22:11-23.

Zou P, Liu X, Wong S, Feng MR, and Liederer BM (2013) Comparison of in vitro-in vivo extrapolation of biliary clearance using an empirical scaling factor versus transport-based scaling factors in sandwich-cultured rat hepatocytes. J Pharm Sci 102:2837-2850. 


\section{Figure Legends}

1. Comparison of IVIVE error (predicted in vivo clearance/observed in vivo clearance) from the metabolic stability incubations with and without serum/albumin addition versus observed in vivo clearance using blood in vivo clearance from the Wood et al. (2017) data set for (A) hepatocytes and (B) microsomes and plasma in vivo clearance from the Lombardo et al. (2018) data set for (C) hepatocytes and (D) microsomes. Dashed lines indicate within 2-fold and dotted lines indicate within 3-fold predictability. Green dots are incubations without serum/albumin addition, while red dots are incubations to which serum/albumin has been added.

2. Comparison of IVIVE error (predicted in vivo clearance/observed in vivo clearance) from the metabolic stability incubations with and without serum/albumin addition versus $f_{u, b}$ for (A) hepatocytes and (B) microsomes and $f_{u, p}$ for (C) hepatocytes and (D) microsomes. Dashed lines indicate within 2-fold and dotted lines indicate within 3-fold predictability. Green dots are incubations without serum/albumin addition, red dots are incubations to which serum/albumin has been added.

3. Comparison of unbound intrinsic clearance from (A) hepatocyte (B) microsomal incubations with and without serum/albumin addition for BDDCS class 1 drugs (blue dots) and class 2 drugs (orange dots). Solid line is line of identity. 


\begin{tabular}{|c|c|c|c|c|c|c|c|c|}
\hline & \multicolumn{4}{|c|}{ Predicted/Observed $\mathrm{CL}_{\mathrm{H}, \mathrm{b}}$} & \multicolumn{4}{|c|}{ Predicted/Observed $\mathrm{CL}_{\mathrm{H}, \mathrm{p}}$} \\
\hline & \multicolumn{2}{|c|}{ without serum } & \multicolumn{2}{|c|}{ with serum } & \multicolumn{2}{|c|}{ without serum } & \multicolumn{2}{|c|}{ with serum } \\
\hline & over 2-fold & within 2-fold & over 2-fold & within 2-fold & over 2-fold & within 2-fold & over 2-fold & withing-fold \\
\hline All drugs & $\begin{array}{c}67.6 \% \\
\text { (n=48 of } 71 \text { ) }\end{array}$ & $\begin{array}{c}32.4 \% \\
(n=23 \text { of } 71)\end{array}$ & $\begin{array}{c}58.9 \% \\
\text { (n=43 of } 73)\end{array}$ & $\begin{array}{c}41.1 \% \\
\text { (n=30 of } 73)\end{array}$ & $\begin{array}{c}82.1 \% \\
(n=55 \text { of } 67)\end{array}$ & $\begin{array}{c}17.9 \% \\
(n=12 \text { of } 67)\end{array}$ & $\begin{array}{c}72.5 \% \\
(n=50 \text { of } 69)\end{array}$ & $(\mathrm{n}=19$ 每 69$)$ \\
\hline Low ER & $\begin{array}{c}68.7 \% \\
\text { (n=22 of } 32)\end{array}$ & $\begin{array}{c}31.3 \% \\
(n=10 \text { of } 32)\end{array}$ & $\begin{array}{c}53.1 \% \\
\text { (n=17 of } 32)\end{array}$ & $\begin{array}{c}46.9 \% \\
\text { (n=15 of } 32)\end{array}$ & $\begin{array}{c}77.3 \% \\
(n=17 \text { of } 22)\end{array}$ & $\begin{array}{c}22.7 \% \\
(n=5 \text { of } 22)\end{array}$ & $\begin{array}{c}50.0 \% \\
\text { (n=11 of } 22)\end{array}$ & $\begin{array}{c}50 . \frac{\mathrm{m}}{\sqrt{3}} \\
\text { (n=11 }\end{array}$ \\
\hline $\begin{array}{c}\text { Moderate } \\
\text { ER }\end{array}$ & $\begin{array}{c}65.5 \% \\
\text { ( } n=19 \text { of } 29)\end{array}$ & $\begin{array}{c}34.5 \% \\
(n=10 \text { of } 29)\end{array}$ & $\begin{array}{c}67.7 \% \\
(n=21 \text { of } 31)\end{array}$ & $\begin{array}{c}32.3 \% \\
(n=10 \text { of } 31)\end{array}$ & $\begin{array}{c}73.3 \% \\
(n=11 \text { of } 15)\end{array}$ & $\begin{array}{c}26.7 \% \\
(n=4 \text { of } 15)\end{array}$ & $\begin{array}{c}68.7 \% \\
(n=11 \text { of } 16)\end{array}$ & $\begin{array}{c}31 . \frac{32 \%}{\underbrace{}_{4}} \\
(\mathrm{n}=5 \mathrm{q}+16)\end{array}$ \\
\hline High ER & $\begin{array}{c}70.0 \% \\
(n=7 \text { of } 10)\end{array}$ & $\begin{array}{c}30.0 \% \\
(n=3 \text { of } 10)\end{array}$ & $\begin{array}{c}50.0 \% \\
(n=5 \text { of } 10)\end{array}$ & $\begin{array}{c}50.0 \% \\
(n=5 \text { of } 10)\end{array}$ & $\begin{array}{c}90.0 \% \\
(n=27 \text { of } 30)\end{array}$ & $\begin{array}{c}10.0 \% \\
(n=3 \text { of } 30)\end{array}$ & $\begin{array}{c}90.3 \% \\
(n=28 \text { of } 31)\end{array}$ & 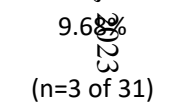 \\
\hline
\end{tabular}




\begin{tabular}{|c|c|c|c|c|c|c|c|c|}
\hline & \multicolumn{4}{|c|}{ Predicted/Observed CL $L_{H, b}$} & \multicolumn{4}{|c|}{ Predicted/Observed $\mathrm{CL}_{\mathrm{H}, \mathrm{p}}$} \\
\hline & \multicolumn{2}{|c|}{ without serum } & \multicolumn{2}{|c|}{ with serum } & \multicolumn{2}{|c|}{ without serum } & \multicolumn{2}{|c|}{ with serum } \\
\hline & over 2-fold & within 2-fold & over 2-fold & within 2-fold & over 2-fold & within 2-fold & over 2-fold & within \\
\hline All drugs & $\begin{array}{c}79.2 \% \\
\text { (n=19 of } 24)\end{array}$ & $\begin{array}{c}20.8 \% \\
\text { ( } n=5 \text { of } 24)\end{array}$ & $\begin{array}{c}62.5 \% \\
(n=15 \text { of } 24)\end{array}$ & $\begin{array}{c}37.5 \% \\
(n=9 \text { of } 24)\end{array}$ & $\begin{array}{c}79.2 \% \\
(n=19 \text { of } 24)\end{array}$ & $\begin{array}{c}20.8 \% \\
(n=5 \text { of } 24)\end{array}$ & $\begin{array}{c}66.7 \% \\
(n=16 \text { of } 24)\end{array}$ & 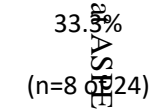 \\
\hline Low ER & $\begin{array}{c}75.0 \% \\
(n=6 \text { of } 8)\end{array}$ & $\begin{array}{c}25.0 \% \\
\text { ( } n=2 \text { of } 8 \text { ) }\end{array}$ & $\begin{array}{c}75.0 \% \\
(n=6 \text { of } 8)\end{array}$ & $\begin{array}{c}25.0 \% \\
(n=2 \text { of } 8)\end{array}$ & $\begin{array}{c}75.0 \% \\
\text { ( } n=6 \text { of } 8 \text { ) }\end{array}$ & $\begin{array}{c}25.0 \% \\
(n=2 \text { of } 8)\end{array}$ & $\begin{array}{c}62.5 \% \\
\text { (n=5 of 8) }\end{array}$ & 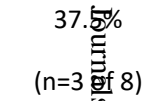 \\
\hline $\begin{array}{c}\text { Moderate } \\
\text { ER }\end{array}$ & $\begin{array}{c}71.4 \% \\
(n=5 \text { of } 7)\end{array}$ & $\begin{array}{c}28.6 \% \\
(n=2 \text { of } 7)\end{array}$ & $\begin{array}{c}57.1 \% \\
\text { ( } n=4 \text { of } 7 \text { ) }\end{array}$ & $\begin{array}{c}42.9 \% \\
\text { (n=3 of } 7)\end{array}$ & $\begin{array}{c}40.0 \% \\
(n=2 \text { of } 5)\end{array}$ & $\begin{array}{c}60.0 \% \\
(n=3 \text { of } 5)\end{array}$ & $\begin{array}{c}0.00 \% \\
\text { (n=0 of } 5)\end{array}$ & 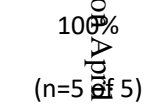 \\
\hline High ER & $\begin{array}{c}88.9 \% \\
\text { ( } n=8 \text { of } 9 \text { ) }\end{array}$ & $\begin{array}{c}11.1 \% \\
\text { (n=1 of 9) }\end{array}$ & $\begin{array}{l}55.6 \% \\
\text { (n=5 of } 9)\end{array}$ & $\begin{array}{c}44.4 \% \\
\text { ( } \mathrm{n}=4 \text { of } 9)\end{array}$ & $\begin{array}{c}100 \% \\
(n=11 \text { of } 11)\end{array}$ & $\begin{array}{c}0.00 \% \\
(n=0 \text { of } 11)\end{array}$ & $\begin{array}{c}100 \% \\
(n=11 \text { of } 11)\end{array}$ & 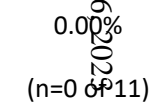 \\
\hline
\end{tabular}




\begin{tabular}{|c|c|c|c|c|c|c|c|c|}
\hline & \multicolumn{4}{|c|}{ Predicted/Observed $\mathrm{CL}_{\mathrm{H}, \mathrm{b}}$} & \multicolumn{4}{|c|}{ Predicted/Observed $\mathrm{CL}_{\mathrm{H}, \mathrm{p}}$} \\
\hline & \multicolumn{2}{|c|}{ without serum } & \multicolumn{2}{|c|}{ with serum } & \multicolumn{2}{|c|}{ without serum } & \multicolumn{2}{|c|}{ with serum } \\
\hline & over 2-fold & within 2-fold & over 2-fold & within 2-fold & over 2-fold & within 2-fold & over 2-fold & within \\
\hline All drugs & $\begin{array}{c}67.6 \% \\
(n=48 \text { of } 71)\end{array}$ & $\begin{array}{c}32.4 \% \\
(n=23 \text { of } 71)\end{array}$ & $\begin{array}{c}58.9 \% \\
(n=43 \text { of } 73)\end{array}$ & $\begin{array}{c}41.1 \% \\
(n=30 \text { of } 73)\end{array}$ & $\begin{array}{c}82.1 \% \\
(n=55 \text { of } 67)\end{array}$ & $\begin{array}{c}17.9 \% \\
(n=12 \text { of } 67)\end{array}$ & $\begin{array}{c}72.5 \% \\
(n=50 \text { of } 69)\end{array}$ & 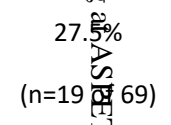 \\
\hline$f_{u}<0.1$ & $\begin{array}{c}85.3 \% \\
(n=29 \text { of } 34)\end{array}$ & $\begin{array}{c}14.7 \% \\
(n=5 \text { of } 34)\end{array}$ & $\begin{array}{c}60.0 \% \\
(n=21 \text { of } 35)\end{array}$ & $\begin{array}{c}40.0 \% \\
(n=14 \text { of } 35)\end{array}$ & $\begin{array}{c}91.2 \% \\
(n=31 \text { of } 34)\end{array}$ & $\begin{array}{c}8.82 \% \\
(n=3 \text { of } 34)\end{array}$ & $\begin{array}{c}62.9 \% \\
(n=22 \text { of } 35)\end{array}$ & (n=13 \\
\hline$f_{u}>0.1$ & $\begin{array}{c}51.4 \% \\
\text { (n=19 of } 37)\end{array}$ & $\begin{array}{c}48.6 \% \\
(n=18 \text { of } 37)\end{array}$ & $\begin{array}{c}57.9 \% \\
(n=22 \text { of } 38)\end{array}$ & $\begin{array}{c}42.1 \% \\
(n=16 \text { of } 38)\end{array}$ & $\begin{array}{c}72.7 \% \\
(n=24 \text { of } 33)\end{array}$ & $\begin{array}{c}27.3 \% \\
(n=9 \text { of } 33)\end{array}$ & $\begin{array}{c}82.4 \% \\
(n=28 \text { of } 34)\end{array}$ & 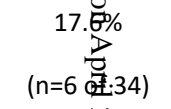 \\
\hline
\end{tabular}




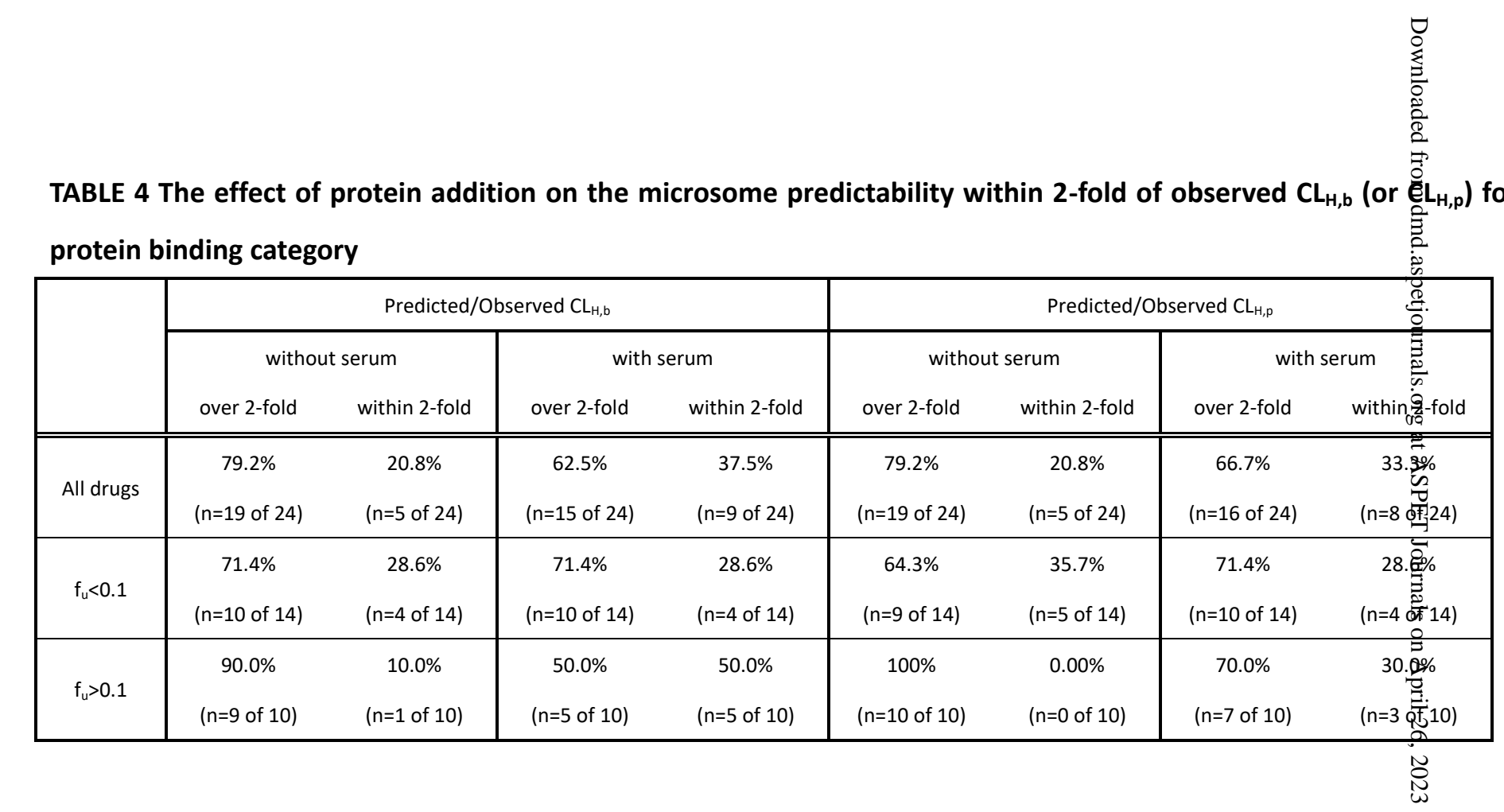




\begin{tabular}{|c|c|c|c|c|c|c|c|c|}
\hline \multicolumn{9}{|c|}{3 drugs and low solubility BDDCS class 2 and 4 drugs } \\
\hline & \multicolumn{4}{|c|}{ Predicted/Observed $\mathrm{CL}_{\mathrm{H}, \mathrm{b}}$} & \multicolumn{4}{|c|}{ Predicted/Observed $\mathrm{CL}_{\mathrm{H}, \mathrm{p}}$} \\
\hline & \multicolumn{2}{|c|}{ without serum } & \multicolumn{2}{|c|}{ with serum } & \multicolumn{2}{|c|}{ without serum } & \multicolumn{2}{|c|}{ with serum } \\
\hline & over 2-fold & within 2-fold & over 2 -fold & within 2-fold & over 2-fold & within 2-fold & over 2-fold & withing-fold \\
\hline $\begin{array}{c}\text { BDDCS } \\
\text { class } \\
1 \text { and } 3\end{array}$ & $\begin{array}{c}60.5 \% \\
(n=26 \text { of } 43)\end{array}$ & $\begin{array}{c}39.5 \% \\
(n=17 \text { of } 43)\end{array}$ & $\begin{array}{c}56.8 \% \\
(n=25 \text { of } 44)\end{array}$ & $\begin{array}{c}43.2 \% \\
(n=19 \text { of } 44)\end{array}$ & $\begin{array}{c}70.1 \% \\
(n=34 \text { of } 43)\end{array}$ & $\begin{array}{c}20.9 \% \\
\text { (n=9 of 43) }\end{array}$ & $\begin{array}{c}79.5 \% \\
(n=35 \text { of } 44)\end{array}$ & 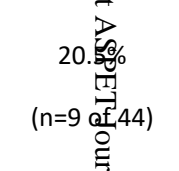 \\
\hline $\begin{array}{c}\text { BDDCS } \\
\text { class } \\
2 \text { and } 4\end{array}$ & $\begin{array}{c}88.6 \% \\
(n=22 \text { of } 28)\end{array}$ & $\begin{array}{c}21.4 \% \\
\text { (n=6 of } 28 \text { ) }\end{array}$ & $\begin{array}{c}52.1 \% \\
(n=18 \text { of } 29)\end{array}$ & $\begin{array}{c}37.9 \% \\
(n=11 \text { of } 29)\end{array}$ & $\begin{array}{c}87.5 \% \\
(n=21 \text { of } 24)\end{array}$ & $\begin{array}{c}12.5 \% \\
\text { ( } n=3 \text { of } 24)\end{array}$ & $\begin{array}{c}60.0 \% \\
(n=15 \text { of } 25)\end{array}$ & 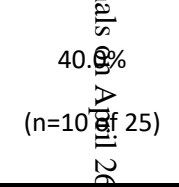 \\
\hline
\end{tabular}


TABLE 6 The effect of protein addition on microsome predictability within 2-fold observed for $\mathrm{CL}_{\mathrm{H}, \mathrm{b}}$ (or $\mathrm{CL}_{\mathrm{H}}^{\mathrm{P}}$ ) by high solubility BDDCS class 1 drugs and low solubility BDDCS class 2 drugs

\begin{tabular}{|c|c|c|c|c|c|c|c|c|}
\hline & \multicolumn{4}{|c|}{ Predicted/Observed $\mathrm{CL}_{\mathrm{H}, \mathrm{b}}$} & \multicolumn{4}{|c|}{ Predicted/Observed $\mathrm{CL}_{\mathrm{H}, \mathrm{p}}$} \\
\hline & \multicolumn{2}{|c|}{ without serum } & \multicolumn{2}{|c|}{ with serum } & \multicolumn{2}{|c|}{ without serum } & \multicolumn{2}{|c|}{ with serum $\underset{0}{\dot{\theta}}$} \\
\hline & over 2-fold & within 2-fold & over 2-fold & within 2-fold & over 2 -fold & within 2-fold & over 2-fold & within $\overrightarrow{3}$-fold \\
\hline BDDCS & $71.4 \%$ & $28.6 \%$ & $42.9 \%$ & $57.1 \%$ & $85.7 \%$ & $14.3 \%$ & $85.7 \%$ & $14.3 \%$ \\
\hline class 1 & $(n=5$ of 7$)$ & $(n=2$ of 7$)$ & $(n=3$ of 7$)$ & $(n=4$ of 7$)$ & $(n=6$ of 7$)$ & $(n=1$ of 7$)$ & $(n=6$ of 7$)$ & $(n=1 \stackrel{g}{g} 7)$ \\
\hline $\begin{array}{l}\text { BDDCS } \\
\text { class } 2\end{array}$ & $\begin{array}{c}82.4 \% \\
(n=14 \text { of } 17)\end{array}$ & $\begin{array}{c}17.6 \% \\
(n=3 \text { of } 17)\end{array}$ & $\begin{array}{c}70.6 \% \\
(n=12 \text { of } 17)\end{array}$ & $\begin{array}{c}29.4 \% \\
(n=5 \text { of } 17)\end{array}$ & $\begin{array}{c}66.5 \% \\
(n=13 \text { of } 17)\end{array}$ & $\begin{array}{c}23.5 \% \\
(n=4 \text { of } 17)\end{array}$ & $\begin{array}{c}58.8 \% \\
(n=10 \text { of } 17)\end{array}$ & $\begin{array}{c}41 . \overrightarrow{2} \% \\
\stackrel{\Xi}{(n=7} \text { of } 17)\end{array}$ \\
\hline & & & & & & & & 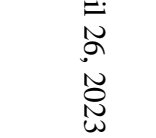 \\
\hline
\end{tabular}


TABLE 7 The effect of protein addition on hepatocyte predictability within 2-fold observed for $\mathrm{CL}_{\mathrm{H}, \mathrm{b}}\left(\right.$ or $\left.\mathrm{CL}_{\mathrm{H}, \mathrm{p}}\right)$ 荑y drugs categorized as acids, bases, neutrals or zwitterions.

\begin{tabular}{|c|c|c|c|c|c|c|c|c|}
\hline & \multicolumn{4}{|c|}{ Predicted/Observed $\mathrm{CL}_{\mathrm{H}, \mathrm{b}}$} & \multicolumn{4}{|c|}{ Predicted/Observed $\mathrm{CL}_{H, p}$} \\
\hline & \multicolumn{2}{|c|}{ without serum } & \multicolumn{2}{|c|}{ with serum } & \multicolumn{2}{|c|}{ without serum } & \multicolumn{2}{|c|}{ with serum } \\
\hline & over 2-fold & within 2-fold & over 2 -fold & within 2-fold & over 2 -fold & within 2-fold & over 2-fold & withing-fold \\
\hline Acids & $\begin{array}{c}88.9 \% \\
(n=16 \text { of } 18)\end{array}$ & $\begin{array}{c}11.1 \% \\
(n=2 \text { of } 18)\end{array}$ & $\begin{array}{c}68.4 \% \\
(n=13 \text { of } 19)\end{array}$ & $\begin{array}{c}31.6 \% \\
(n=6 \text { of } 19)\end{array}$ & $\begin{array}{c}94.1 \% \\
\text { ( } n=16 \text { of } 17)\end{array}$ & $\begin{array}{c}5.9 \% \\
\text { (n=1 of } 17)\end{array}$ & $\begin{array}{c}66.7 \% \\
(n=12 \text { of } 18)\end{array}$ & 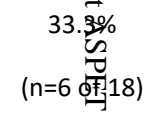 \\
\hline Bases & $\begin{array}{c}54.8 \% \\
(n=17 \text { of } 31)\end{array}$ & $\begin{array}{c}45.2 \% \\
(n=14 \text { of } 31)\end{array}$ & $\begin{array}{c}53.1 \% \\
(n=17 \text { of } 32)\end{array}$ & $\begin{array}{c}46.9 \% \\
(n=15 \text { of } 32)\end{array}$ & $\begin{array}{c}77.4 \% \\
(n=24 \text { of } 31)\end{array}$ & $\begin{array}{c}22.6 \% \\
(n=7 \text { of } 31)\end{array}$ & $\begin{array}{c}71.9 \% \\
(n=23 \text { of } 32)\end{array}$ & 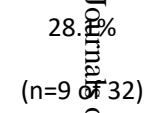 \\
\hline Neutrals & $\begin{array}{c}75.0 \% \\
(n=13 \text { of } 20)\end{array}$ & $\begin{array}{c}35.0 \% \\
(n=7 \text { of } 20)\end{array}$ & $\begin{array}{c}60.0 \% \\
(n=12 \text { of } 20)\end{array}$ & $\begin{array}{c}40.0 \% \\
(n=8 \text { of } 20)\end{array}$ & $\begin{array}{c}76.5 \% \\
\text { (n=13 of } 17)\end{array}$ & $\begin{array}{c}23.5 \% \\
(n=4 \text { of } 17)\end{array}$ & $\begin{array}{c}82.4 \% \\
(n=14 \text { of } 17)\end{array}$ & (n=3 施17) \\
\hline Zwitterions & $\begin{array}{c}100 \% \\
(n=2 \text { of } 2)\end{array}$ & $\begin{array}{c}0.00 \% \\
(n=0 \text { of } 2)\end{array}$ & $\begin{array}{c}50.0 \% \\
(n=1 \text { of } 2)\end{array}$ & $\begin{array}{c}50.0 \% \\
(n=1 \text { of } 2 \text { ) }\end{array}$ & $\begin{array}{c}100 \% \\
(n=2 \text { of } 2)\end{array}$ & $\begin{array}{c}0.00 \% \\
(n=0 \text { of } 2)\end{array}$ & $\begin{array}{c}50.0 \% \\
(n=1 \text { of } 2)\end{array}$ & $\begin{array}{c}50.02 \% \\
\text { (n=1 of } 2)\end{array}$ \\
\hline
\end{tabular}




\begin{tabular}{|c|c|c|c|c|c|c|c|c|}
\hline \multirow{3}{*}{$\begin{array}{l}\text { TABLE } 8 \text { T } \\
\text { neutrals }\end{array}$} & \multicolumn{4}{|c|}{ Predicted/Observed $\mathrm{CL}_{\mathrm{H}, \mathrm{b}}$} & \multicolumn{4}{|c|}{ Predicted/Observed $\mathrm{CL}_{\mathrm{H}, \mathrm{p}}$} \\
\hline & \multicolumn{2}{|c|}{ without serum } & \multicolumn{2}{|c|}{ with serum } & \multicolumn{2}{|c|}{ without serum } & \multicolumn{2}{|c|}{ with serum } \\
\hline & over 2-fold & within 2-fold & over 2-fold & within 2-fold & over 2-fold & within 2-fold & over 2-fold & within $\dot{q}_{0}$-fold \\
\hline Acids & $\begin{array}{c}75.0 \% \\
(n=9 \text { of } 12)\end{array}$ & $\begin{array}{c}25.0 \% \\
(n=3 \text { of } 12)\end{array}$ & $\begin{array}{c}50.0 \% \\
(n=6 \text { of } 12)\end{array}$ & $\begin{array}{c}50.0 \% \\
(n=6 \text { of } 12)\end{array}$ & $\begin{array}{c}66.7 \% \\
(n=8 \text { of } 12)\end{array}$ & $\begin{array}{c}33.3 \% \\
(n=4 \text { of } 12)\end{array}$ & $\begin{array}{c}50.0 \% \\
(n=6 \text { of } 12)\end{array}$ & 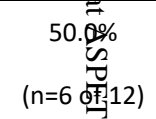 \\
\hline Bases & $\begin{array}{c}0.00 \% \\
(n=0 \text { of } 1)\end{array}$ & $\begin{array}{c}100 \% \\
(n=1 \text { of } 1)\end{array}$ & $\begin{array}{c}0.00 \% \\
(n=0 \text { of } 1)\end{array}$ & $\begin{array}{c}100 \% \\
(n=1 \text { of } 1)\end{array}$ & $\begin{array}{c}0.00 \% \\
(n=0 \text { of } 1)\end{array}$ & $\begin{array}{c}100 \% \\
(n=1 \text { of } 1)\end{array}$ & $\begin{array}{c}0.00 \% \\
(n=0 \text { of } 1)\end{array}$ & 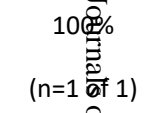 \\
\hline Neutrals & $\begin{array}{c}88.9 \% \\
(n=8 \text { of } 9)\end{array}$ & $\begin{array}{c}11.1 \% \\
(n=1 \text { of } 9)\end{array}$ & $\begin{array}{c}88.9 \% \\
(n=8 \text { of } 9)\end{array}$ & $\begin{array}{c}11.1 \% \\
(n=1 \text { of } 9)\end{array}$ & $\begin{array}{c}100 \% \\
(n=9 \text { of } 9)\end{array}$ & $\begin{array}{c}0.00 \% \\
(n=0 \text { of } 9)\end{array}$ & $\begin{array}{c}88.9 \% \\
(n=8 \text { of } 9)\end{array}$ & (n=1 \\
\hline Zwitterions & $\begin{array}{c}100 \% \\
(n=2 \text { of } 2)\end{array}$ & $\begin{array}{c}0.00 \% \\
(n=0 \text { of } 2)\end{array}$ & $\begin{array}{c}100 \% \\
(n=2 \text { of } 2)\end{array}$ & $\begin{array}{c}0.00 \% \\
(n=0 \text { of } 2)\end{array}$ & $\begin{array}{c}100 \% \\
(n=2 \text { of } 2)\end{array}$ & $\begin{array}{c}0.00 \% \\
(n=0 \text { of } 2)\end{array}$ & $\begin{array}{c}100 \% \\
(n=2 \text { of } 2)\end{array}$ & $\begin{array}{c}0.0 \operatorname{gog}^{\mathrm{N}} \% \\
\text { (n=0 of 2) }\end{array}$ \\
\hline
\end{tabular}


TABLE 9 Analysis of reported data from hepatocyte and microsomal incubations for comparison of the change of predicted in vivo $\mathrm{CL}_{\text {int }}$

$\left(\mathrm{CL}_{\text {int,in vivo,with protein }} / \mathrm{CL}_{\text {int, in vivo,without protein }}\right)$ in terms of BDDCS class.

\begin{tabular}{|c|c|c|c|c|c|}
\hline & & \multicolumn{4}{|c|}{$\mathrm{CL}_{\text {int,in vivo, with protein }} / \mathrm{CL}_{\text {int,in vivo, without protein }}$} \\
\hline & & All & Decrease & Increase $<2$-fold & Increase $>2$-fold \\
\hline \multirow{5}{*}{ Hepatocytes } & All drugs & 73 & $\begin{array}{c}42.5 \% \\
\text { (31 of } 73 \text { ) }\end{array}$ & $\begin{array}{c}15.1 \% \\
(11 \text { of } 73)\end{array}$ & $\begin{array}{c}42.5 \% \\
\text { (31 of } 73 \text { ) }\end{array}$ \\
\hline & $\begin{array}{l}\text { BDDCS } \\
\text { Class } 1\end{array}$ & 41 & $\begin{array}{c}51.2 \% \\
\text { (21 of } 41 \text { ) }\end{array}$ & $\begin{array}{c}17.1 \% \\
(7 \text { of } 41)\end{array}$ & $\begin{array}{c}31.7 \% \\
(13 \text { of } 41)\end{array}$ \\
\hline & $\begin{array}{l}\text { BDDCS } \\
\text { Class } 2\end{array}$ & 27 & $\begin{array}{c}33.3 \% \\
\text { (9 of } 27 \text { ) }\end{array}$ & $\begin{array}{c}11.1 \% \\
\text { (3 of } 27)\end{array}$ & $\begin{array}{c}55.6 \% \\
\text { (15 of } 27 \text { ) }\end{array}$ \\
\hline & $\begin{array}{l}\text { BDDCS } \\
\text { Class } 3\end{array}$ & 3 & $\begin{array}{l}33.3 \% \\
(1 \text { of } 3)\end{array}$ & $\begin{array}{l}33.3 \% \\
(1 \text { of } 3)\end{array}$ & $\begin{array}{l}33.3 \% \\
(1 \text { of } 3)\end{array}$ \\
\hline & $\begin{array}{l}\text { BDDCS } \\
\text { Class } 4\end{array}$ & 2 & $\begin{array}{l}0.00 \% \\
(0 \text { of } 2)\end{array}$ & $\begin{array}{l}0.00 \% \\
(0 \text { of } 2)\end{array}$ & $\begin{array}{c}100 \% \\
(2 \text { of } 2)\end{array}$ \\
\hline \multirow{3}{*}{ Microsomes } & All drugs & 24 & $\begin{array}{c}12.5 \% \\
(3 \text { of } 24)\end{array}$ & $\begin{array}{c}20.8 \% \\
\text { (5 of } 24)\end{array}$ & $\begin{array}{c}66.7 \% \\
\text { (16 of } 24)\end{array}$ \\
\hline & $\begin{array}{l}\text { BDDCS } \\
\text { Class } 1\end{array}$ & 7 & $\begin{array}{l}14.3 \% \\
(1 \text { of } 7)\end{array}$ & $\begin{array}{l}42.9 \% \\
(3 \text { of } 7)\end{array}$ & $\begin{array}{l}42.9 \% \\
(3 \text { of } 7)\end{array}$ \\
\hline & $\begin{array}{l}\text { BDDCS } \\
\text { Class } 2\end{array}$ & 17 & $\begin{array}{c}11.8 \% \\
(2 \text { of } 17)\end{array}$ & $\begin{array}{c}11.8 \% \\
\text { (2 of } 17 \text { ) }\end{array}$ & $\begin{array}{c}76.5 \% \\
\text { (13 of } 17)\end{array}$ \\
\hline
\end{tabular}


Fig 1.

A.

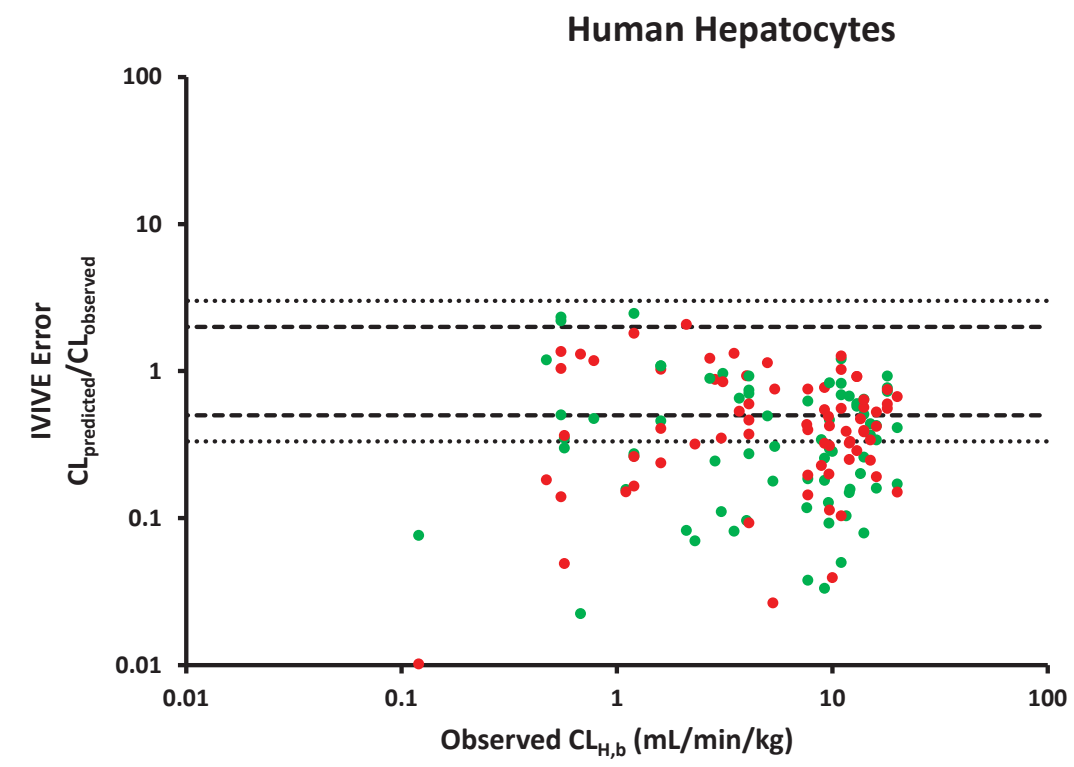

- without serum

- with serum

B.

Human Liver Microsomes

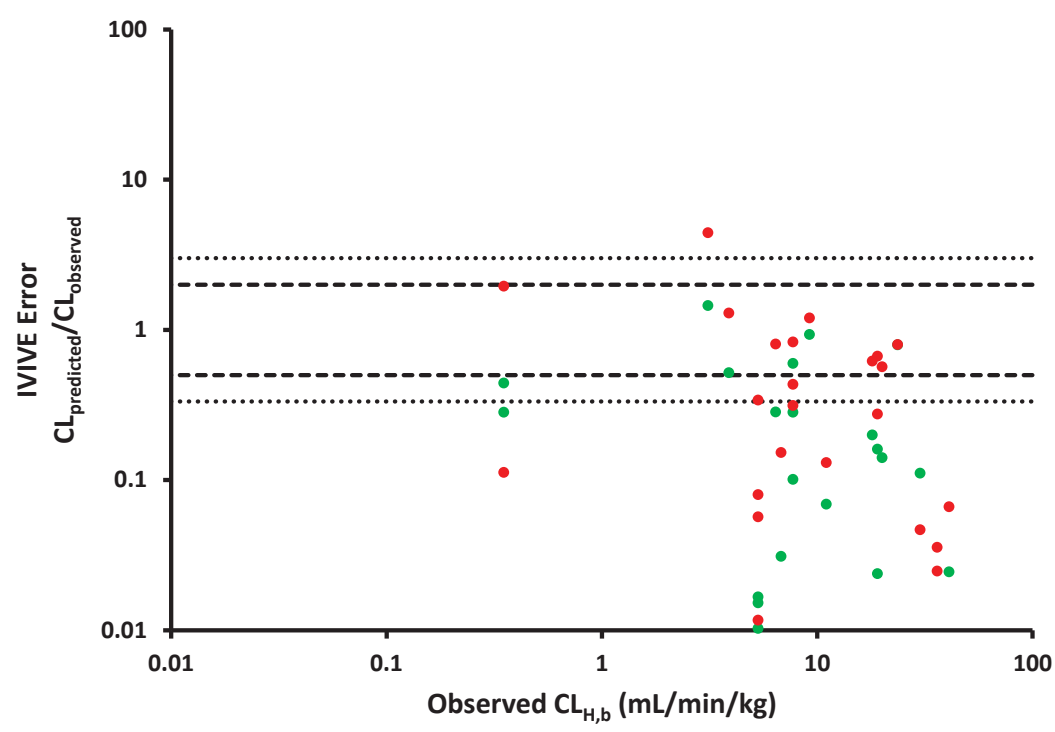

- without serum

- with serum 
C.

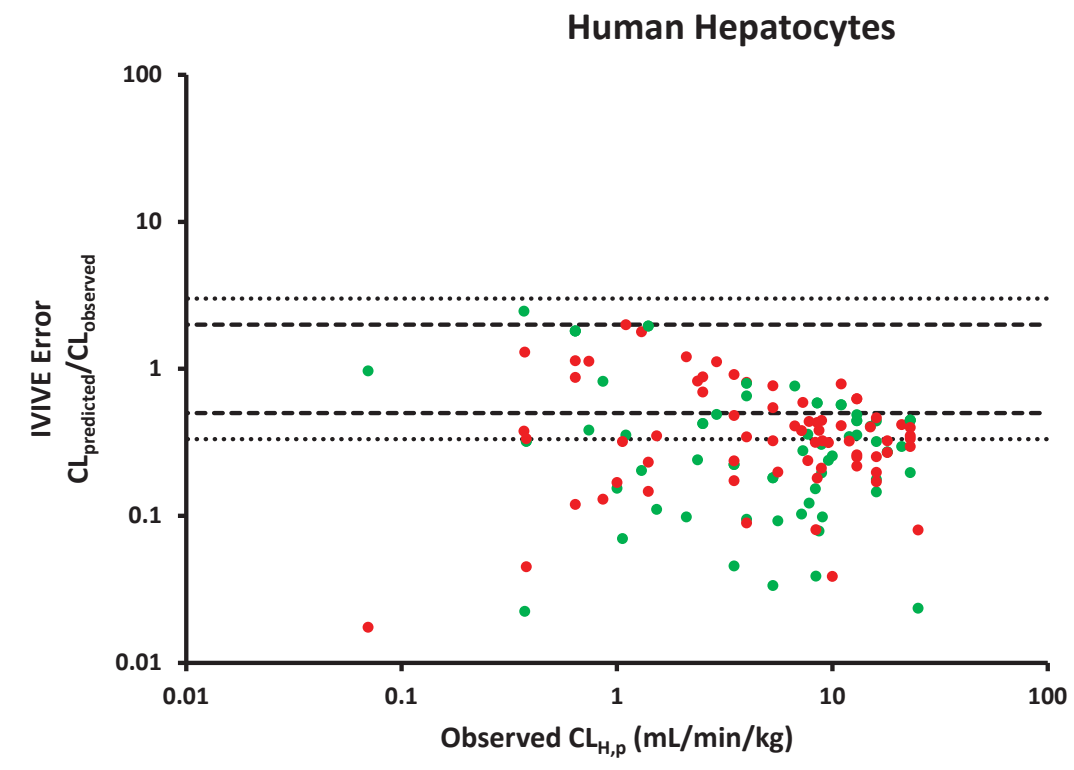

- without serum - with serum

D.

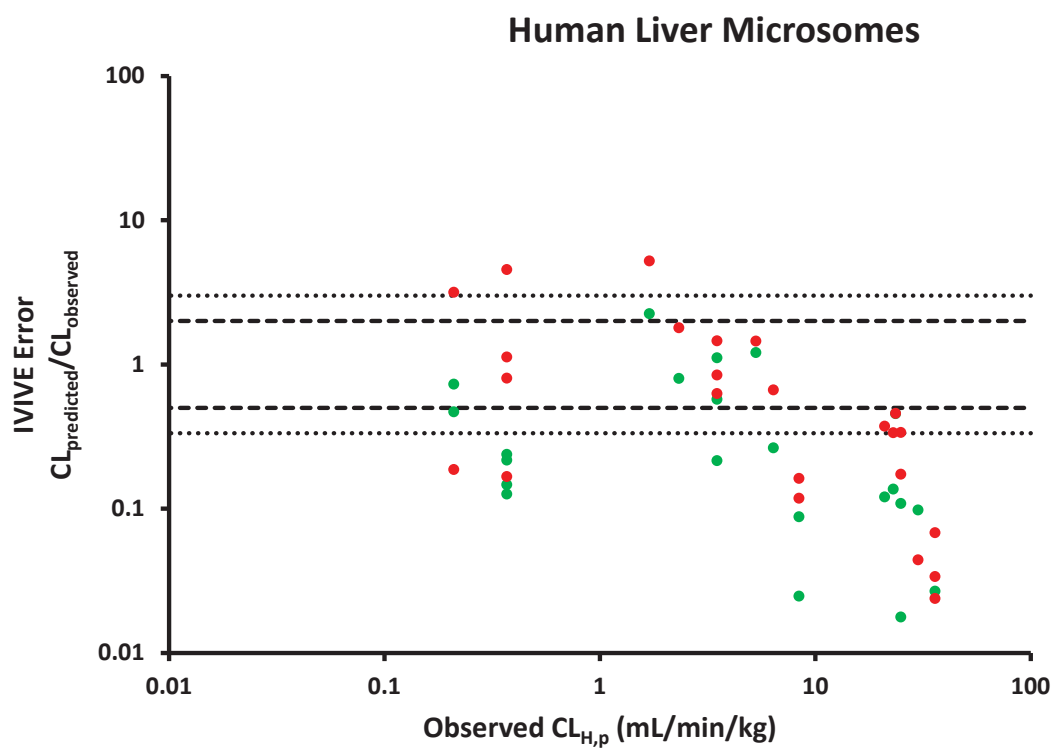

- without albumin

- with albumin 
Fig. 2

A.

\section{Human Hepatocytes}

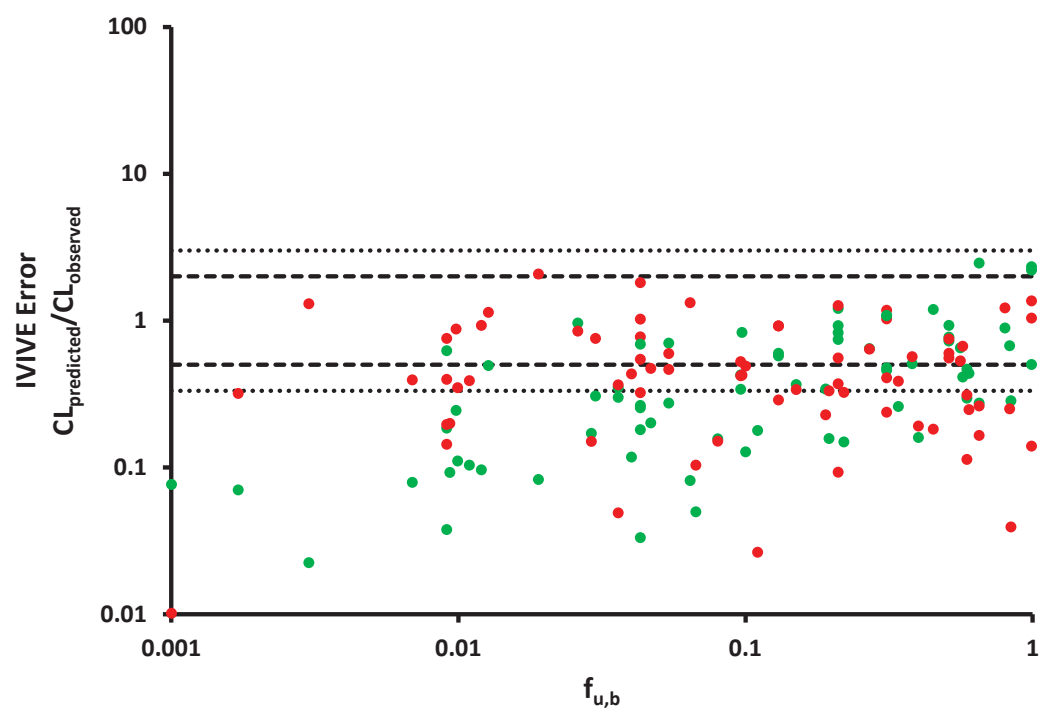

- without serum

- with serum

B.

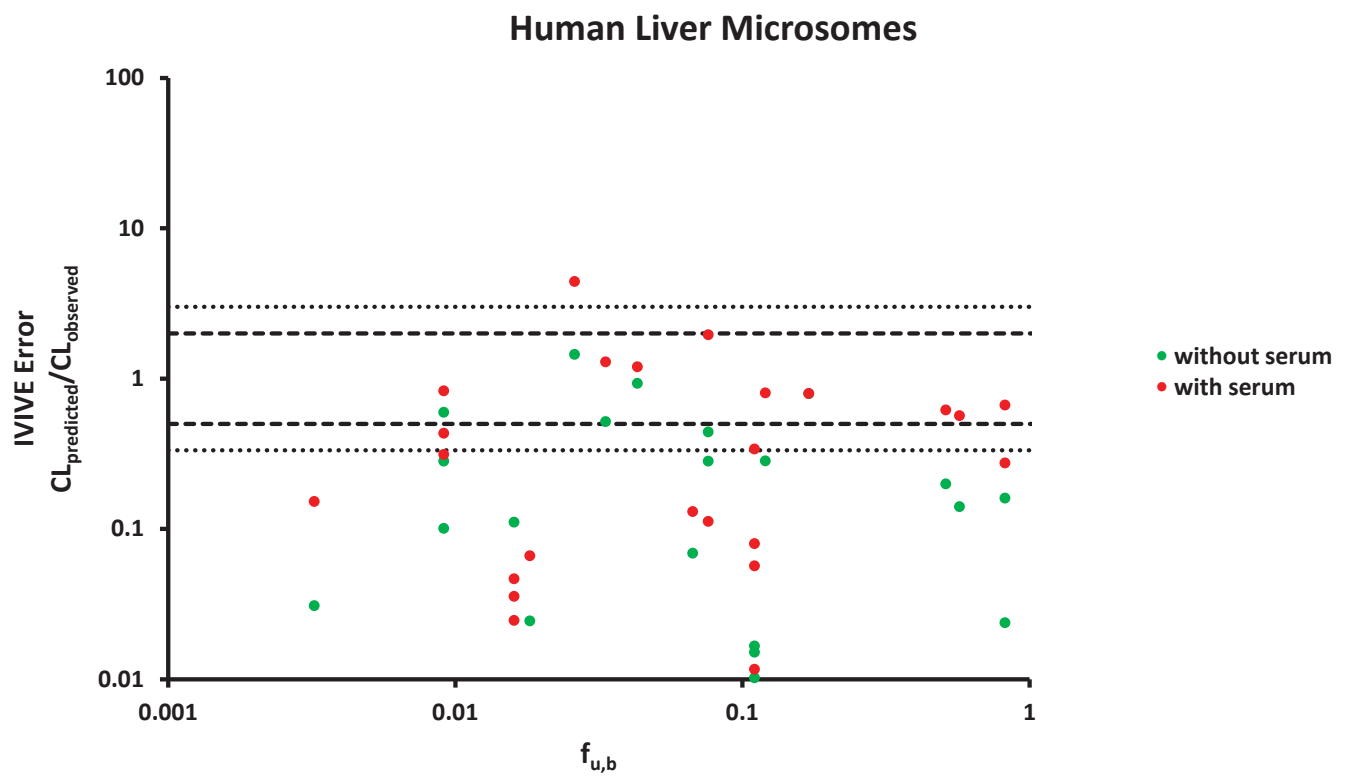


C.

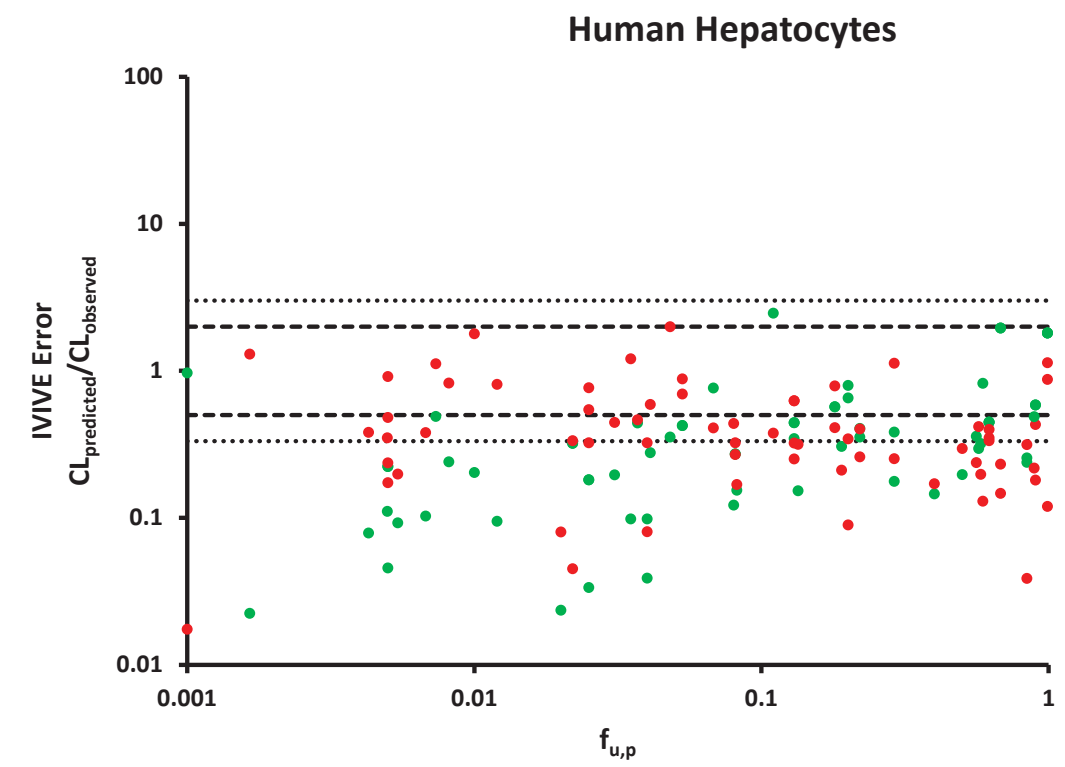

- without serum

- with serum

D.

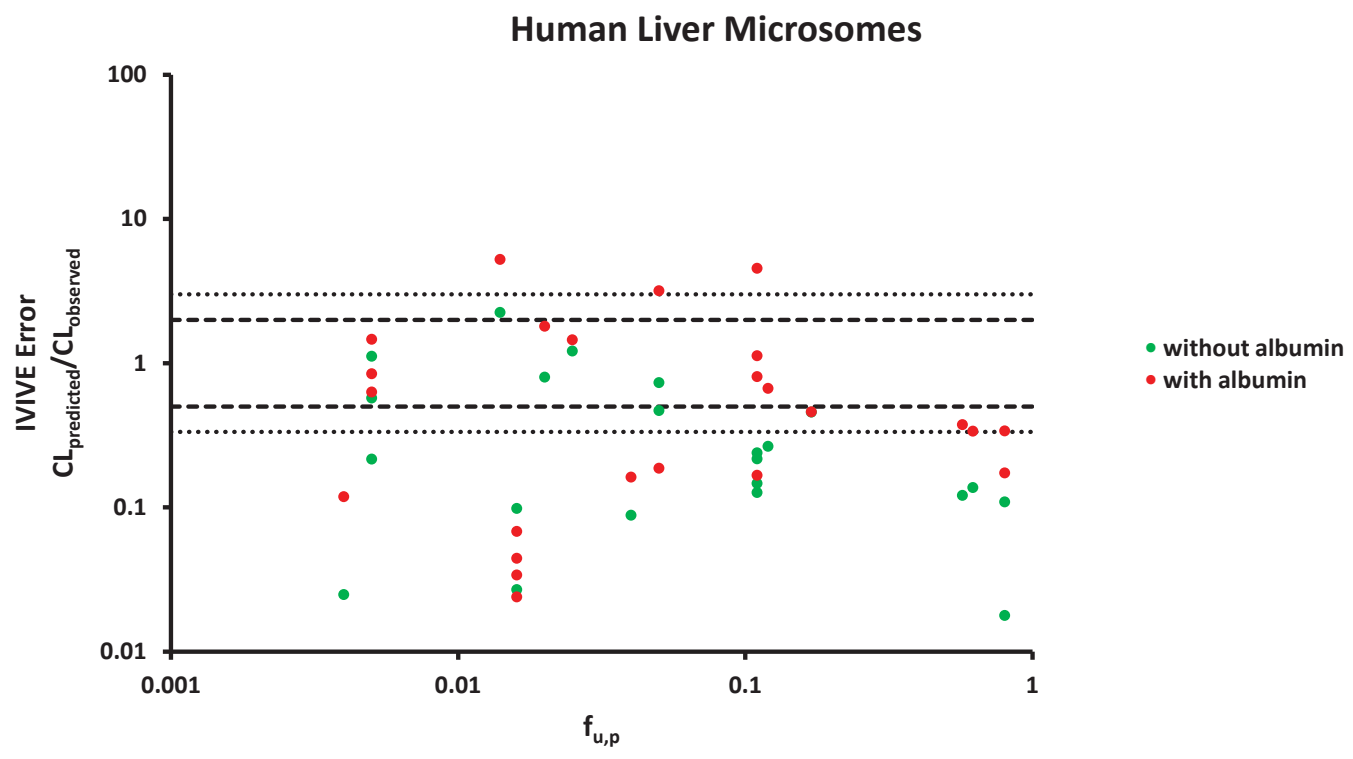


Fig. 3

A.

\section{Human Hepatocytes}

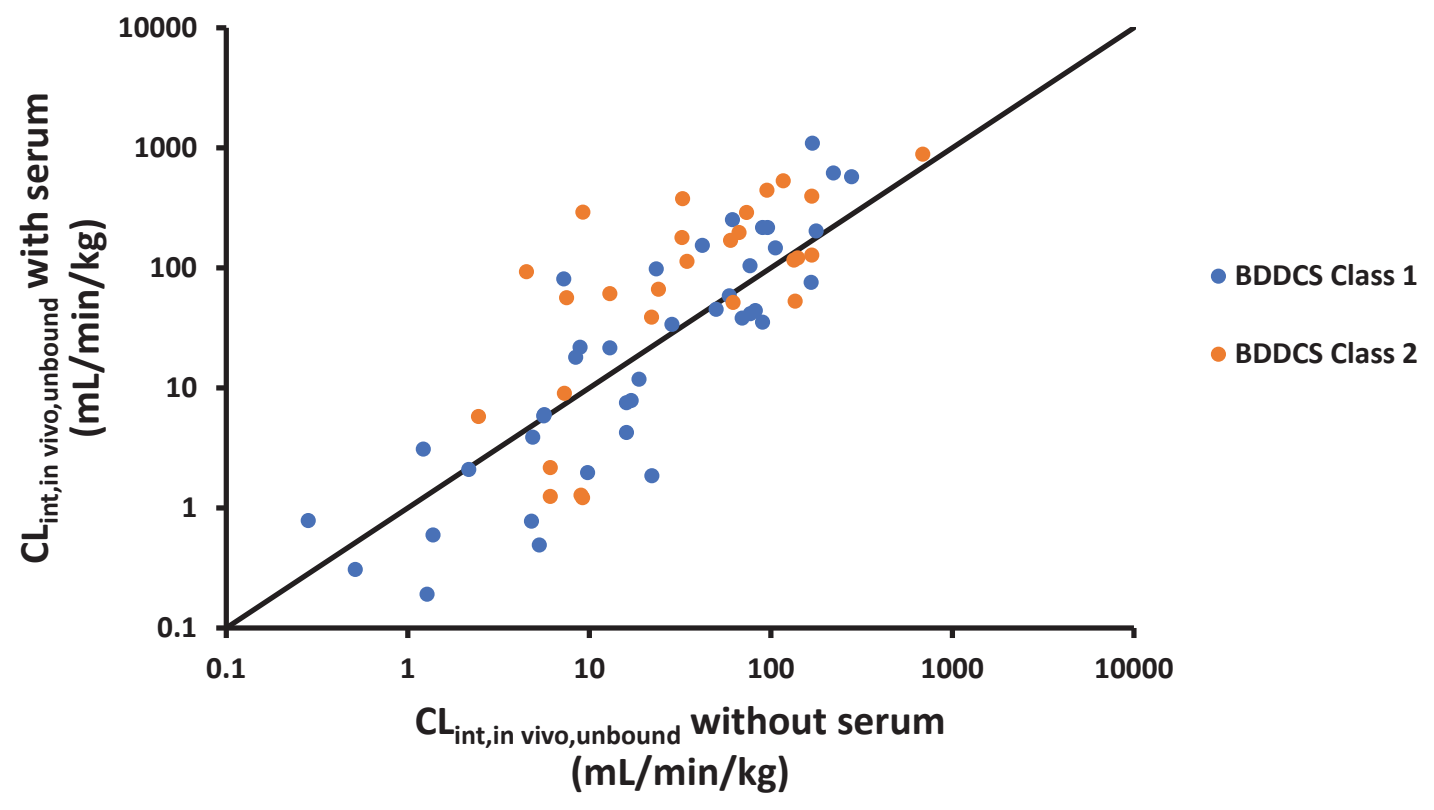

B.

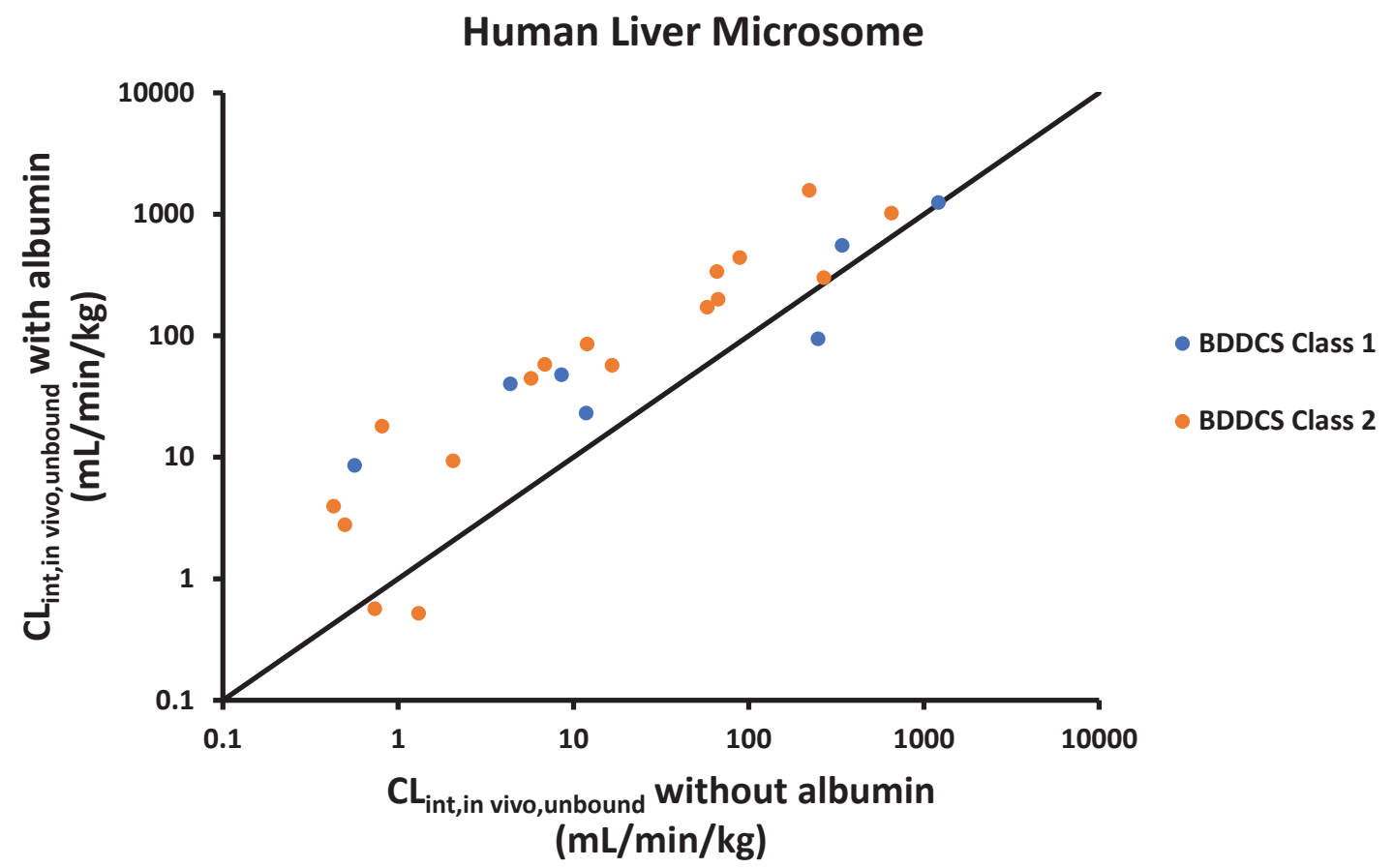

